\title{
A Structural Impact Assessment of Flaws Detected During Ultrasonic Examination of Tank 15
}

\author{
B. J. Wiersma \\ J. B. Elder \\ Savannah River National Laboratory \\ Materials Science and Technology Directorate
}

Publication Date: August 2008

This document was prepared in conjunction with work accomplished under Contract No. DE-AC0908SR22470 with the U. S. Department of Energy

\section{We Put Science To Work}

The Savannah River National Laboratory is managed and operated for the U.S. Department of Energy by

S A V A N N A R R I ER N U C LEAR SOLU TIONS, L L C AIKEN, SC USA 29808 • SRNL.DOE.GOV 


\section{DISCLAIMER}

This report was prepared under an agreement with and funded by the U. S. Government. Neither the U. S. Government or its employees, nor any of its contractors, subcontractors or their employees, makes any express or implied: 1 . warranty or assumes any legal liability for the accuracy, completeness, or for the use of results of such use of any information, product or process disclosed; or 2. representation that such use or results of such use would not infringe privately owned rights; or 3 . endorsement or recommendation of any specifically identified commercial product, process or service. Any views and opinions of authors expressed in this work do not necessarily state or reflect those of the United States Government, or its contractors, or subcontractors. 


\section{APPROVALS}

Date:

B. J. Wiersma, AUTHOR

Materials Performance and Corrosion Technology Group MATERIALS TECHNOLOGY SECTION

Date:

J. B. Elder, AUTHOR

Materials Performance and Corrosion Technology Group

MATERIALS SCIENCE AND TECHNOLOGY DIRECTORATE

Date:

R. L. Sindelar, TECHNICAL REVIEWER

MATERIALS SCIENCE AND TECHNOLOGY DIRECTORATE

Date:

R. W. VandeKamp, TECHNICAL REVIEWER

Materials Performance and Corrosion Technology Group

MATERIALS SCIENCE AND TECHNOLOGY DIRECTORATE

$\overline{\text { K. H. Subramanian, MANAGER }}$

Date:

Materials Performance and Corrosion Technology Group

MATERIALS SCIENCE AND TECHNOLOGY DIRECTORATE

N. C. Iyer, Director

Date:

MATERIALS SCIENCE AND TECHNOLOGY DIRECTORATE

E. J. Freed, MANAGER

Date:

H-Tank Farm Facility Engineering Manager

LIQUID WASTE ORGANIZATION

Date:

$\overline{\text { A. S. Plummer, TECHNICAL REVIEWER }}$

H\&F Tank Farm Engineering

Mechanical Engineering

LIQUID WASTE ORGANIZATION
C. E. Blair, MANAGER

Date:

H\&F Tank Farm Engineering

Mechanical Engineering

LIQUID WASTE ORGANIZATION 


\section{Table of Contents}

$1.0 \quad$ Executive Summary....................................................................................................................... 1

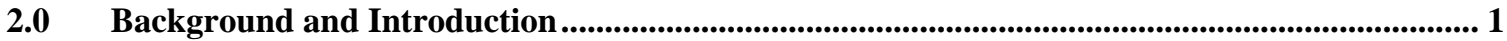

3.0 Summary of Historical Flaw Characteristics and Behavior .............................................................. 2

3.3 Data from Samples Extracted from the Wall of Tank 16 ...................................................... 5

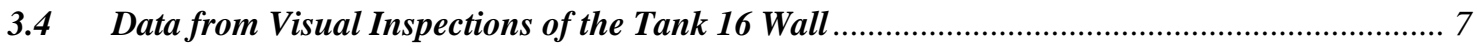

3.5 Data from Dye-Penetrant Examination of the Tank 16 Wall .................................................... 7

3.6 Data from Laboratory Studies on Welded Steel Plates.............................................................. 8

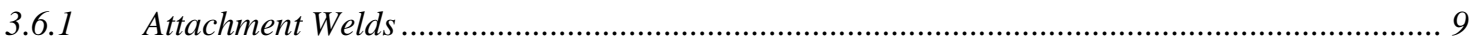

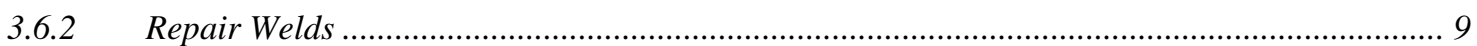

3.7 Data from Residual Stress Modeling of Various Weld Configurations ...................................... 10

3.7.1 Vertical and Horizontal Seam Welds.......................................................................................... 10

3.7.2 Intersection of Horizontal and Vertical Seam Welds............................................................... 11

3.7.3 Repair Welds ................................................................................................................... 13

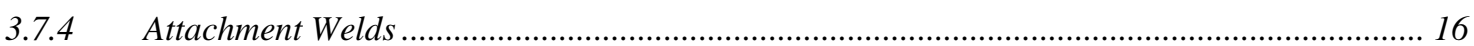

4.0 Analysis of Crack Data From Recent Ultrasonic Inspection ............................................................ 16

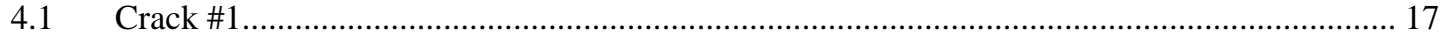

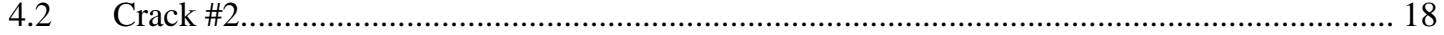

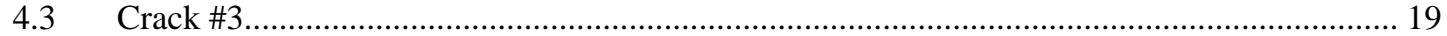

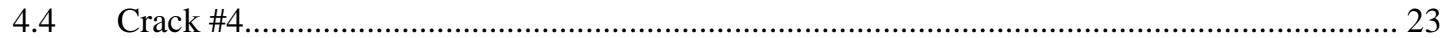

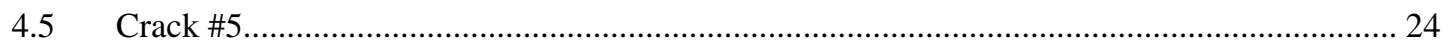

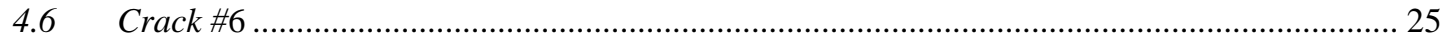

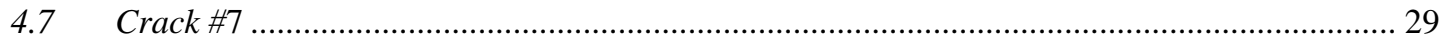

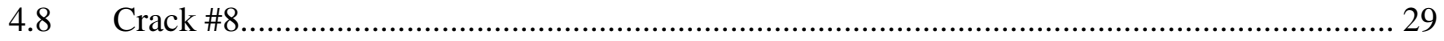

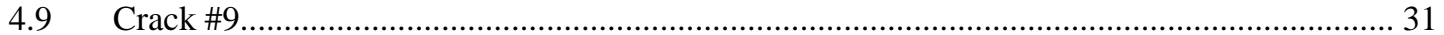

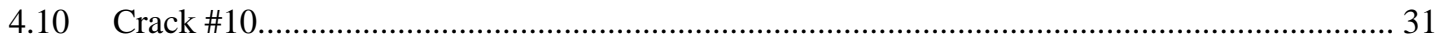

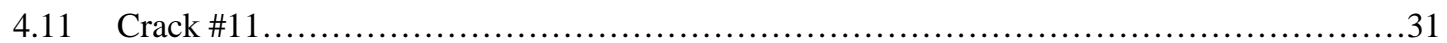

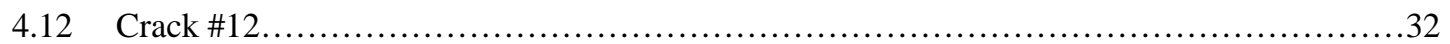

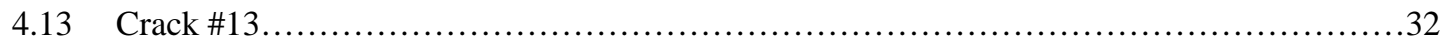

5.0 Crack Specific Evaluations ................................................................................................................ 32

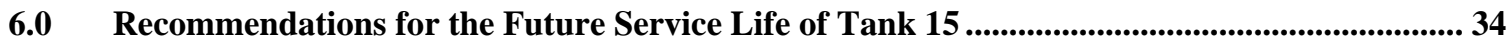

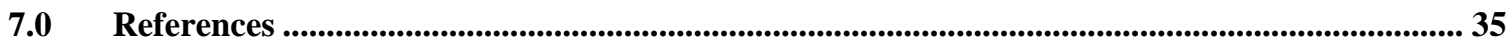

\section{APPENDIX}




\subsection{Executive Summary}

Ultrasonic (UT) inspection of Tank 15 was conducted between April and July 2007 in accordance with the Tank 15 UT inspection plan. This was a planned re-inspection of this tank, the previous one was performed in 2002. Ten cracks were characterized in the previous examination. The re-inspection was performed to verify the present models and understanding for stress corrosion cracking.

During this re-examination, one indication that was initially reported as a "possible perpendicular crack $<25 \%$ through wall" in 2002, was clearly shown not to be a crack. Additionally, examination of a new area immediately adjacent to other cracks along a vertical weld revealed three new cracks. It is not known when these new cracks formed as they could very well have been present in 2002 as well. Therefore, a total of twelve cracks were evaluated during the re-examination.

A critical review of the information describing stress corrosion crack behavior for the SRS waste tanks, as well as a summary review of the service history of Tank 15, was performed. Each crack was then evaluated for service exposure history, consistency of the crack behavior with the current understanding of stress corrosion cracking, and present and future impact to the structural integrity of the tank. Crack instability calculations were performed on each crack for a bounding waste removal loading condition in Tank 15.

In all cases, the crack behavior was determined to be consistent with the previous understanding of stress corrosion cracking in the SRS waste tank environment. The length of the cracks was limited due to the short-range nature of the residual stresses near seam, repair and attachment welds. Of the twelve cracks, nine were located in the vapor space above the sludge layer, including the three new cracks. Comparison of the crack lengths measured in 2002 and 2007 revealed that crack growth had occurred in four of the six previously measured vapor space cracks. However, the growth remained within the residual stress zone. None of the three cracks beneath the sludge showed evidence of growth.

The impact of the cracks that grew on the future service of Tank 15 was also assessed. Tank 15 is expected to undergo closure activities including sludge waste removal. A bounding loading condition for waste removal of the sludge at the bottom of Tank 15 was considered for this analysis. The analysis showed that the combination of hydrostatic, seismic, pump and weld residual stresses are not expected to drive any of the cracks identified during the Tank 15 UT inspection to instability.

Wall thickness mapping for general thinning and pitting was also performed. No significant wall thinning was observed. The average wall thickness values were well above nominal. Two isolated pit-like indications were observed. Both were approximately 30 mils deep. However, the remaining wall thickness was still greater than nominal specified for the original construction plate material.

It was recommended that a third examination of selected cracks in Tank 15 be performed in 2014. This examination would provide information to determine whether any additional detectable degradation is occurring in Tank 15 and to supplement the basis for characterization of conditions that are non-aggressive to tank corrosion damage.

The in-service inspection program is re-evaluated on a three year periodicity. The Type I and II tanks are not active receipt tanks at present, and are therefore not a part of the In-Service Inspection Program for the Type III Tanks [1]. Changes to the mission for Tank 15 and other Type I and II tanks may be considered by the In-Service Inspection Review Committee (ISIRC) and the program adjusted accordingly.

\subsection{Background and Introduction}

Ultrasonic inspection of Tank 15 was conducted between April and July 2007. The primary focus was to re-examine 10 cracks that were characterized in 2002 [2]. The results of the inspection were reported separately [3]. 
Tank 15, like all other Type II waste tanks, leaked waste into the annulus during its service life. In most cases these leak sites were attributed to nitrate stress corrosion cracking [4]. The Type II tanks are not actively receiving waste, and the operations management has provided for safe storage of the waste in these tanks prior to waste removal and tank closure activities.

With the discovery that an unusual crack existed in Tank 15 in 1994 [5], there was a desire to investigate whether this crack, or others that might be discovered, could be explained based on the understanding of tank service history, material properties, and residual stress distributions. Additionally, the routine inspection plan for the Type III tanks, which focuses on weld seams and vertical strips of base metal, was followed for this specific Type II tank.

This document provides a critical review of the information describing stress corrosion crack behavior for the SRS waste tanks as well as a summary review of the service history of Tank 15. Each crack was then evaluated for service exposure history, consistency of the crack behavior with the current understanding of stress corrosion cracking, and present and future impact to the structural integrity of the tank. Flawspecific analyses were performed on cracks that grew since 2002. Each of these cracks exceeded the current reference flaw size (i.e., 6 inches) [6].

Wall thickness mapping for general thinning and pitting was also performed as part of the re-inspection of Tank 15 [3]. No significant wall thinning was observed. The average wall thickness values were well above nominal. Two isolated pit-like indications were observed. Both were approximately 30 mils deep. However, the remaining wall thickness was still greater than nominal specified for original construction.

\subsection{Summary of Historical Flaw Characteristics and Behavior}

Much of what is known with regard to flaws in waste tanks at SRS was learned in conjunction with the leakage incident in Tank 16 that occurred in the early 1960s. Data on flaw characteristics was gathered through visual inspections of the tank, destructive examination of a tank sample and laboratory testing on welded plates. A review of these data will be useful given the similarity in materials of construction, fabrication, and service history between Tanks 15 and 16.

\subsection{Materials of Construction}

Flaw characteristics and behavior are dependent on the materials of construction and the environment to which the material was exposed. The carbon steel material for both Tanks 15 and 16 was formed per specification ASTM A285-50T, Grade B firebox quality (A285). The nominal composition and mechanical properties are shown in Table 1 [7]. The material was melted in an open-hearth furnace, semikilled and then hot rolled into plate. The rimmed process was not utilized. The material was suitable for submerged arc welding. The construction records were reviewed and it was determined that Tanks 15 and 16 were fabricated from the same heats of steel [5].

Table 1. ASTM Requirements for Chemical Composition and Tensile Properties for A285-50T, Grade B Firebox Quality.

\begin{tabular}{|l|c|c|c|c|c|c|c|}
\hline & \multicolumn{4}{|c|}{ Composition } & \multicolumn{3}{c|}{ Mechanical Properties Ranges } \\
\hline & $\mathrm{C}$ & $\mathrm{Mn}$ & $\mathrm{P}$ & $\mathrm{S}$ & $\begin{array}{c}\text { Tensile } \\
(\mathrm{ksi})\end{array}$ & Yield (ksi) & $\begin{array}{c}\text { \% Elong. } \\
(8 ”)\end{array}$ \\
\hline $\begin{array}{l}\text { For plates } \leq 0.75 ” \\
\text { in thickness }\end{array}$ & 0.2 & 0.8 & 0.035 & 0.04 & $50-60$ & 27 & 27 \\
\hline
\end{tabular}

Compositions are max. wt. \% and yield and elongation properties are min. values.

Cracks are typically located near seam welds, weld repairs, and weld attachments [5]. Two welding procedures were utilized for the Tanks 15 and 16: shielded metal arc welding (SMAW) and submerged arc welding (SAW) [5]. The SMAW technique was utilized exclusively on the vertical welds of the primary tank. Surfaces that were to be welded were cleaned so that they were free of loose scale, clay, rust, grease, paint, and other foreign material. Joint surfaces were smooth and free of defects. Each layer of metal on 
multi-layer welds was cleaned of slag before the next layer of weld material was applied. The weld was cleaned between passes by either chipping or grinding. Cleaning the surface by gas gouging was not permitted. Intermittent welding was not allowed. Defects in welds were chipped, flame gouged, or otherwise machined out until sound metal was reached on all sides. The cavity was then filled with new metal. The welding edges were uniform and smooth and free of slag. Neither Tank 15 nor 16 was stressrelieved after welding.

\subsection{Service Environment}

The environment may be determined by a review of the service history of the tanks. The early service history of Tank 16 is recorded in reference 8 and summarized here. Tank 16 was placed into service as a fresh waste receiver on May 9, 1959. The tank received waste from the enriched uranium recovery (HM) process in 221-H. Six months later on November 13, 1959 radioactive liquid was detected in the annulus beneath the north riser. The maximum temperature of the supernate at the top horizontal weld was approximately $54^{\circ} \mathrm{C}$. In February 1960, visual inspection of the bottom horizontal weld in the south riser indicated leakage was occurring near a repair in the weld. Radiography of the weld at that time indicated that the weld had been repaired satisfactorily. The tank was filled to its capacity (303 inches) by May 1960. During most of the time period between May and September 1960 the annulus ventilation was not in service and hence the annulus remained very damp. Finally in September 1960, the liquid in the annulus rose above the 5 foot annulus pan by an estimated 700 gallons. Most of the overflow was likely contained in the concrete encasement, but an estimated few tens of gallons may have leaked into the ground. It is estimated that the maximum total leakage rate from all the cracks was approximately 4 gallons per minute. Waste was transferred from the annulus to Tanks 15 and 14, until the leakage subsided. The transfers were discontinued at a waste level slightly below the middle horizontal weld (147 inches) of Tank 16.

Transfer of Low Heat waste was initiated in October 1967 since there had been no recurrence of leakage and the self-sealing capability of leaks, given sufficient dehumidification, had been demonstrated. By June 1968, the tank had been filled to its reduced capacity level, approximately 18 inches below the top horizontal weld (Note: Top horizontal weld is at approximately 270 inches). Therefore, a region of approximately 100 inches that had been exposed to a vapor space environment for seven years was once again exposed to waste. In August 1969, a blend of High Heat waste and concentrated supernate from a salt tank was transferred into Tank 16. A year later in May 1970, High Heat waste that was decanted from radioactive and thermally hot sludge was transferred into the tank. In March 1972, use of Tank 16 for storage was discontinued due to the resumption of leakage. The supernate was removed from the tank and a sludge heel of approximately 20 inches remained. The heel was removed in 1979. Waste still remains in the annulus in the form of salt deposits.

The service history of Tank 15 is very closely linked to that of Tank 16 [5]. Tank 15 was placed into radioactive waste service in October 1960, when it received 369,000 gallons of waste transferred from Tank 16 (to lower the waste height in Tank 16 below numerous leak sites). Thereafter the principal service of Tank 15 was as a high-heat waste receiver from 1961 to 1972. Tank 15 received primarily waste from the enriched uranium (HM) process; some low-heat and thorex process waste was received also. The tank was filled with fresh waste five times to near its allowed maximum height of 306 in. (about 1,060,000 gallons) between 1961-72. Between fillings, sludge was allowed to settle and supernate was then transferred to Tank 13 to create space for the next fresh waste receipt. Thus sludge steadily accumulated to a level of approximately 90 inches in 1972. At that time the supernate level was approximately 272 inches. Evaporation of supernate in the years 1972-1978 reduced the waste level to approximately 248 inches. In 1978 supernate was again decanted from Tank 15 in two transfers to create space for the receipts of sludge slurry and rinse water from Tank 16. Two transfers from Tank 16 in 1979 and 1980 raised the Tank 15 sludge level to between 105 and 111 inches, and total waste level to 228 inches. The last major activity for Tank 15 was the suspension of the sludge with slurry pumps and the transfer of the sludge slurry to Tank 42. In March 1982, two transfers of sludge slurry to Tank 42 totaling 727,000 gallons were completed.

Since 1982 Tank 15 has been inactive. Total volume has declined as the supernate evaporated to no measureable liquid after 1988 . The present waste volume is 240,000 gallons of sludge. The sludge level is 
not constant but varies across the tank from approximately 71 inches to 35 inches as measured by the reel tape.

Table 2 shows a history of the supernate chemistry in Tank 15 [5]. The corrosive species is nitrate, while nitrite and hydroxide are corrosion inhibitors. The supernate concentration listed December 1972 is representative of the HM waste that was transferred from the canyon to this tank from 1960-72. A decrease in the concentrations was observed in 1979 due to the addition of slurried sludge from Tank 16. A year later this concentration increased to the previous values probably due to diffusion of the components from the heavy salt solution into the dilute layer. In September of 1980 another batch of slurried sludge was received from Tank 16. The sample that was taken is representative of the dilute phase. A year later, diffusion again resulted in an increase in the concentrations. In 1982, sludge from Tank 15 was slurried and sent to Tank 42. This operation diluted the supernate. Since then there have been no operations in Tank 15. The sample taken in September 1984 seems to give a spurious result. The sample taken in December 1987 did not meet the requirements of the corrosion control program (i.e., not enough hydroxide). Another sample was taken in March 1988 to confirm the result, however, in this case the sample did meet the requirements of the corrosion control program and the sample was considered to be more representative than the December 1987 sample [9]. Since 1988, there has not been a sufficient amount of supernate in Tank 15 to sample.

Table 2. Results of Sampling for Supernate Chemistry

\begin{tabular}{|r|r|r|r|r|r|}
\hline Date & $\begin{array}{l}\text { Specific } \\
\text { Gravity }\end{array}$ & \multicolumn{1}{l|}{$\begin{array}{l}\text { p H itrite } \\
(\mathrm{M})\end{array}$} & $\begin{array}{l}\text { N itrate } \\
(\mathrm{M})\end{array}$ & $\begin{array}{l}\text { H ydroxide } \\
(\mathrm{M})\end{array}$ \\
\hline $03 / 07 / 88$ & 1.266 & 13.600 & 0.096 & 1.100 & 1.116 \\
\hline $12 / 01 / 87$ & 1.230 & 13.260 & 1.400 & 1.570 & 0.073 \\
\hline $09 / 06 / 85$ & 1.170 & 12.900 & 0.860 & 1.300 & 0.220 \\
\hline $12 / 11 / 84$ & 1.105 & 13.180 & 0.680 & 1.180 & 0.136 \\
\hline $09 / 20 / 84$ & 1.147 & 13.410 & 1.750 & 3.400 & 0.159 \\
\hline $03 / 03 / 82$ & 1.170 & & 0.580 & 1.440 & 0.510 \\
\hline $02 / 19 / 82$ & & & 0.650 & 1.680 & 0.860 \\
\hline $09 / 10 / 81$ & 1.240 & 12.400 & 0.600 & 2.100 & 0.800 \\
\hline $09 / 22 / 80$ & 1.060 & 13.400 & $<0.1$ & 0.200 & 0.400 \\
\hline $04 / 25 / 80$ & 1.260 & 11.200 & 0.800 & 4.100 & 1.200 \\
\hline $03 / 03 / 79$ & & & 0.350 & 3.000 & 1.520 \\
\hline $12 / 19 / 72$ & 1.290 & & 1.100 & 3.600 & 1.000 \\
\hline
\end{tabular}

An assessment of the Tank 15 vapor space environment during the past decade was performed [10]. The report indicates that there was evidence for high humidity conditions in the primary tank vapor space. The source of the high humidity was suspected to be the annulus air that communicates with the primary tank via an annulus jet. During the late 1980s and early 1990s the annulus ventilation pre-heater was not operable or had steam leaks. Additionally, rainwater that leaked through the risers remained in the annulus. The combination of these two events created a very humid annulus. The purge ventilation is also a potential source of humid air since it is not pre-heated. The air is circulated through the primary at approximately $300 \mathrm{cfm}$. The primary purpose of the purge ventilation has been to prevent the build-up of flammable gases such as hydrogen, not to maintain a dry environment in the tank. The purge and annulus ventilation operation capacity between 1994 and 1998 is shown in Figure 1. The plot shows that during the summer months (i.e., air has higher moisture content) the annulus ventilation system was typically operated more than $70 \%$ of the time. During the winter months, the annulus ventilation system (i.e., air has lower moisture content) was typically operated $30 \%$ of the time. Thus it appears that an attempt to reduce the 
moisture content in the annulus is being made. The purge ventilation operation time has been severely limited due to emission issues (e.g., a low of $2 \%$ in 1998).

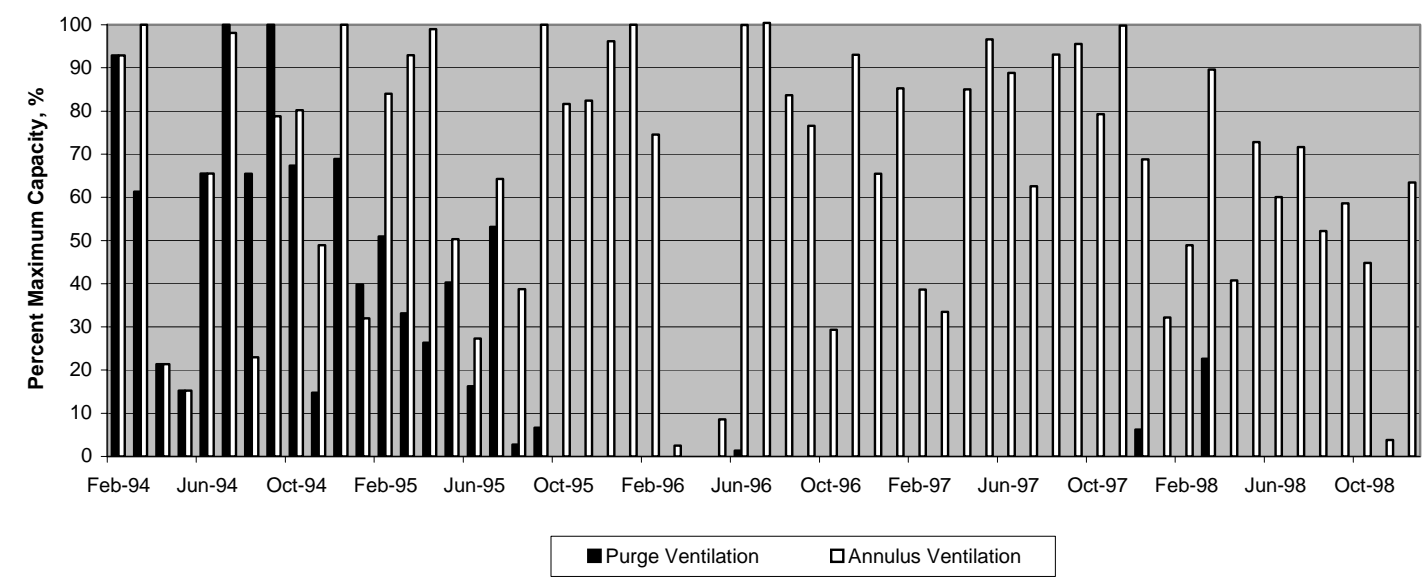

Figure 1. Operational capacity of the Tank 15 annulus and purge ventilation.

Samples from the Tank 15 HEPA filter were utilized to estimate the concentration of nitrate in the vapor space. The maximum nitrate concentration in the vapor space was estimated to be $4 \mu \mathrm{g} / \mathrm{ft}^{3}$ based on total content of nitrate on the filter, flow rate and operation time. However, no estimates of any other potentially aggressive species (e.g., chloride) or inhibitor species such as nitrite or hydroxide were made. No estimation of the actual surface chemistry of condensate at the tank wall can be determined at this time.

\subsection{Data from Samples Extracted from the Wall of Tank 16}

Two disks, each 5 5/8 inches in diameter, were extracted from the wall of Tank 16 in 1961 [11]. The disks were extracted from the horizontal weld between the upper knuckle and the upper primary shell plate and both contained leak sites. The samples had been exposed to HM waste for approximately 7 months.

Metallographic examination revealed the following:

- Three cracks were visibly observed on one of the samples (see Figure 2), with two of the cracks being through-wall. The cracks were intergranular and essentially perpendicular to the horizontal weld. 


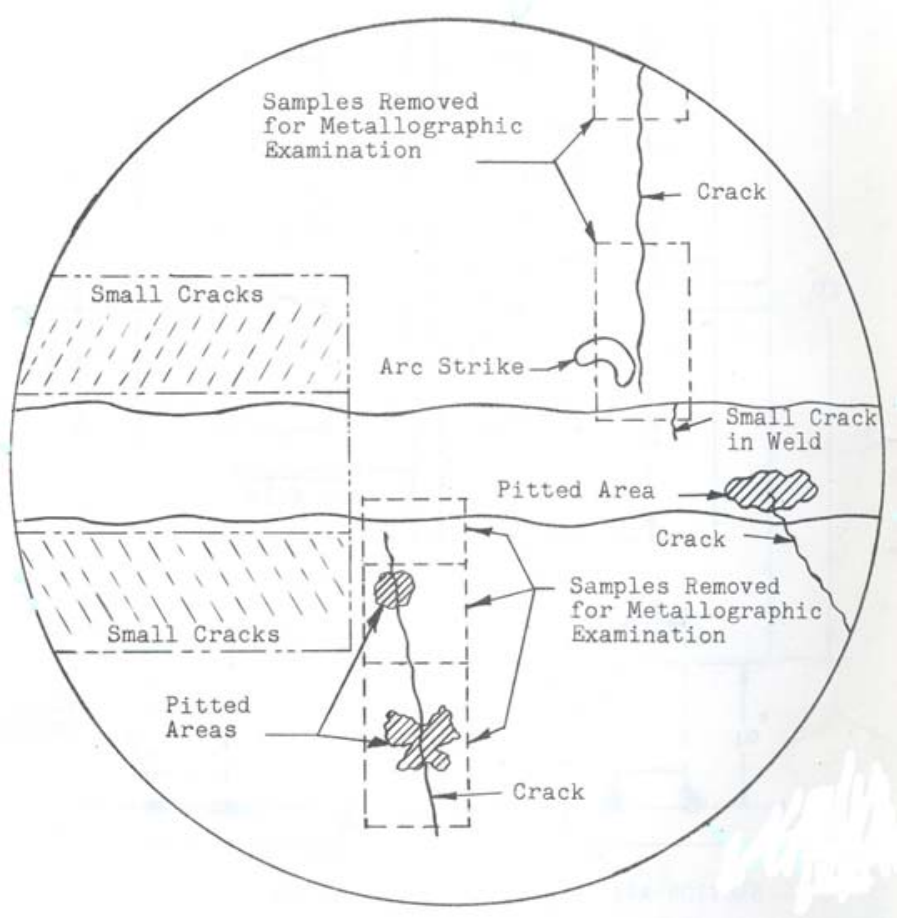

Figure 2. Drawing of interior surface of sample removed from Tank $16 \mathrm{H}$.

- $\quad$ Numerous small cracks were observed on the inner surface (see Figure 3). These cracks were located in both the knuckle and primary shell plates in bands approximately 0.5 inch wide. The edge of these bands was located between 0.0625 and 0.125 inch from the edge of the weld. The cracks ranged from 0.0625 to 0.5 inch in length and were 0.031 inch deep.

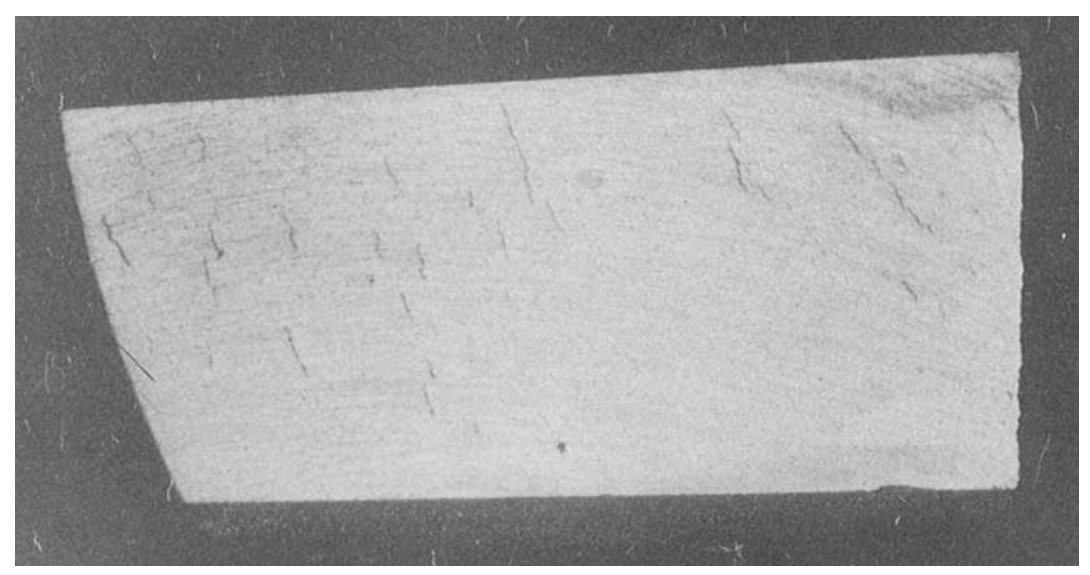

Figure 3. Shallow cracks on interior surface of Tank 16 sample.

- $\quad$ Severe stress raisers (e.g., arc strikes, weld beads, weld repairs, etc.) were not required to initiate the cracks, but may have been required to propagate the cracks.

- The microstructure of the sample was consistent with the theory that the presence of grain boundary carbides in low carbon steel increases the tendency towards intergranular cracking. These carbides would be re-dissolved, and hence not present in the weld or immediately adjacent to the weld. This 
observation would explain why the two major cracks did not propagate into the weld and the numerous surface cracks did not extend into the narrow zone immediately adjacent to the weld.

- Shallow pitting occurred at several locations. The pits were broad and approximately 0.02 inch deep at the site of very tightly adherent deposits. Microscopic pits were associated with the intergranular cracks.

\subsection{Data from Visual Inspections of the Tank 16 Wall}

Visual inspections were performed on the Tank 16 primary wall shortly after waste leakage was detected [12, 13]. Approximately 73\% of the primary wall was inspected during 1961-62 and regions where leak sites were most prominent were identified. The same regions were examined in 1973-74 after the waste had been decanted for the final time. The results of these inspections are summarized below.

1961-62

- $\quad$ Approximately 145 leak sites were identified. The leaks were observed on all three horizontal welds, three vertical welds in the upper primary shell, and at several mid-plate sites.

- $\quad$ The Design Division compared photographs of three leaks at the top horizontal weld with construction radiographs and was able to correlate the leaks with weld repairs. Two leaks occurred at sites where an alignment plate was attached during construction and the other occurred where extra weld metal was deposited on the interior.

- $\quad$ The leaks in this tank were fairly well distributed between the three horizontal welds. This result is in contrast to Tank 14 where all the leaks were located along the bottom horizontal weld.

- $\quad$ A mid-plate leak was sandblasted and examined by periscope and reflectoscope (a type of ultrasonic measurement). The reflectoscope inspection revealed an attachment on the tank wall near the leak site.

1973-74

- $\quad$ Salt deposits on the walls at previously observed leak sites were thicker than before, indicating seepage during the period of time between the inspections. The largest salt deposit was observed on a vertical weld in the upper shell primary plate. A second significant salt deposit was observed beneath the middle horizontal weld.

- $\quad$ The survey indicated that the wall contained an estimated 350 leak sites. An exact count of the number of leak sites was not feasible due to larger salt deposits obscuring the smaller ones.

- A comparison of the two inspections indicated that new leak sites had formed. The majority of the new leak sites were observed on the bottom horizontal weld. There was only one or two new indications within the 100” zone that had a vapor space environment for seven years. However, it should be noted that this region was covered with supernate for the final five years prior to decanting the waste.

- $\quad$ The top weld, where several leak sites were observed in 1961-62, was not exposed to waste. Therefore it is unknown if any new leak sites developed in this region.

\subsection{Data from Dye-Penetrant Examination of the Tank 16 Wall}

In June 1962, the vertical weld in the upper primary shell beneath inspection port 151 was sandblasted and then inspected with dye penetrant [12]. Ten large cracks were visible without magnification. The cracks were essentially perpendicular to the weld bead (see Figure 4). Four of the cracks were estimated to be between 4 to 6 inches long. The radiograph of the vertical weld and the photographs revealed exterior surface imperfections as well as internal weld beads. Although three of the cracks appeared to be associated with weld beads, most of the cracks showed no correlation with known fabrication blemishes. One crack appeared to be slightly curved, however, this crack was located next to a repair weld at the intersection of the vertical weld and the middle horizontal weld. All of the cracks appeared to be in a 3inch zone next to the weld and therefore likely affected by fabrication residual stresses. One crack was observed near a repair weld at the intersection of the vertical and horizontal weld. The crack had an arc like appearance (see Figure 5). 


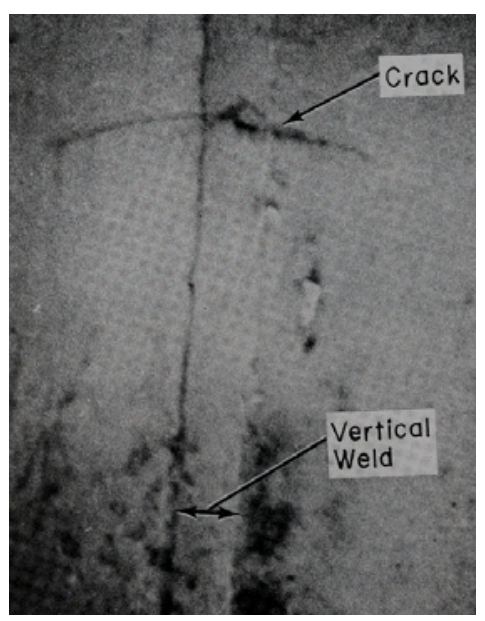

Figure 4. Dye-penetrant testing of stress corrosion crack on vertical weld in Tank 16 [12].

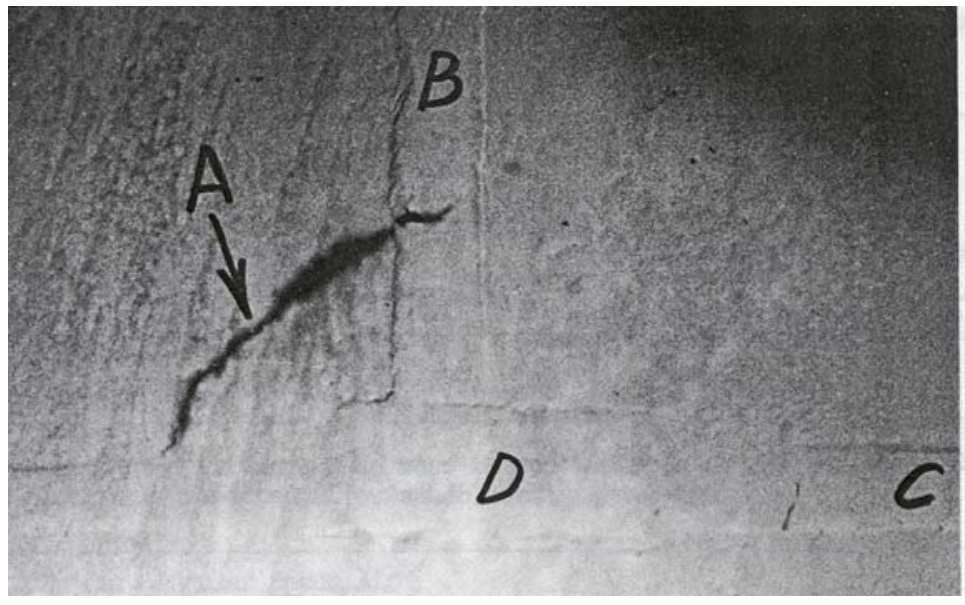

Figure 5. Dye-Penetrant testing at the intersection of vertical and middle horizontal weld in Tank 16: A) crack, B) vertical weld, C) middle horizontal weld, D) repair weld [12].

In January 1974, the same weld was sandblasted and re-inspected with dye penetrant [14]. The cracks did not appear to have increased in size since the 1962 inspection. This result indicated that weld residual stresses were the primary crack driving force.

\subsection{Data from Laboratory Studies on Welded Steel Plates}

A laboratory corrosion test program was performed to determine the failure mechanism in carbon steel tanks [15]. Welded test specimens were exposed to a simulated waste solution ( $5 \mathrm{M}$ nitrate at $97^{\circ} \mathrm{C}$ ) to induce stress corrosion cracking. Attachment and weld repairs were tested as well as seam welds. The crack patterns that developed around these welds were similar to those observed in the tank. These patterns are summarized below. These tests also showed that a full stress relief of a welded specimen successfully prevented initiation of a stress corrosion crack. The full stress relief procedure was:

1) Place the specimens in the furnace when the furnace temperature is less than $316^{\circ} \mathrm{C}$. 
2) Control the heating rate of the furnace such that between 316 to $593{ }^{\circ} \mathrm{C}$, the temperature does not increase at a rate greater than $200^{\circ} \mathrm{C} /$ hour.

3) Maintain the temperature at $593^{\circ} \mathrm{C}$ for 30 minutes.

4) Control the cooling rate of the furnace such that between 593 to $316^{\circ} \mathrm{C}$, the temperature does not decrease at a rate greater than $260^{\circ} \mathrm{C} /$ hour.

\subsubsection{Attachment Welds}

Figure 6 shows the crack pattern associated with a weld attachment. Weld attachments are typically fillet welds rather than full penetration welds. An arc-like crack that curves through the center of the attachment was observed. It is also interesting to note that the attachment redistributes the residual stresses so that the crack that is roughly perpendicular to the seam weld begins to arc. It is difficult to distinguish whether the crack initiated from the seam or the attachment.

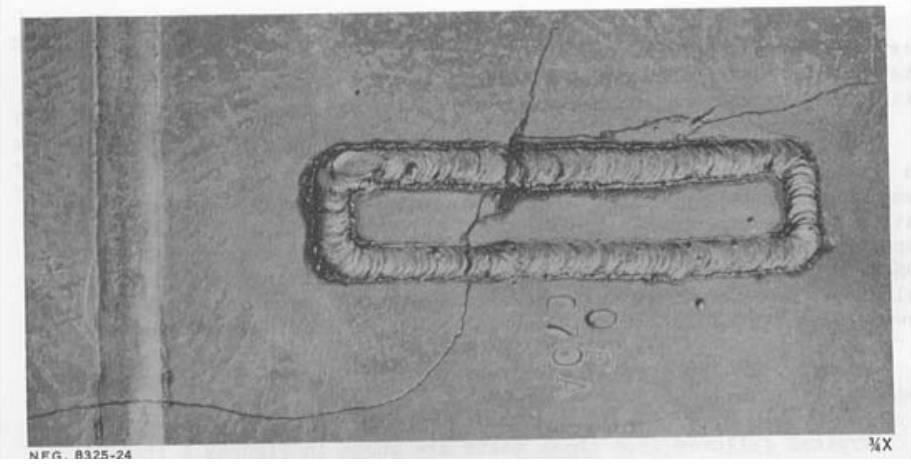

Figure 6. Stress corrosion cracking in area near weld attachment [15].

\subsubsection{Repair Welds}

Figure 7 shows the crack pattern associated with a weld repair. A repair weld is performed to remove defects found in weld beads and the base material during pre-service radiography inspections. During repair, a groove is prepared by grinding out the original weld metal. The repair groove is then filled with new metal. The actual repair length, width and depth may vary depending on the defect size. Cracks were observed proceeding both through and around a repair weld, although the latter was more frequently observed. Typically the crack traces an arc-like path around the repair and then tends to radiate from the corners.

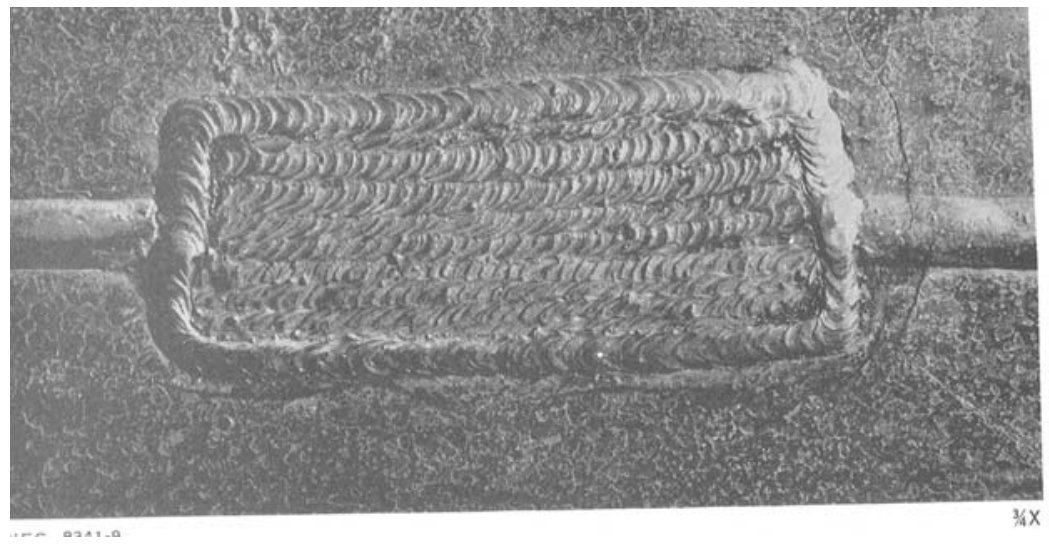

Figure 7. Crack pattern near a weld repair [15]. 


\subsection{Data from Residual Stress Modeling of Various Weld Configurations}

In 1999, SRS contracted Battelle to utilize finite element methods to model the initial condition of the residual stresses and stress intensity factors $(\mathrm{K})$ as a function of crack length for various weld configurations [16-18]. The residual stresses provide the driving force for stress corrosion cracking. If $\mathrm{K}$ is greater than $\mathrm{K}_{\mathrm{Iscc}}$, cracks will propagate through-wall. $\mathrm{K}_{\mathrm{Iscc}}$ for carbon steel in simulated waste environment is on average $28 \mathrm{ksi}$ in ${ }^{1 / 2}$ [19]. The range of values for $\mathrm{K}_{\text {Iscc }}$ was between 24 to $32 \mathrm{ksi}$ in ${ }^{1 / 2}$. Recent tests have confirmed this as a reasonable value [20].

The models [16-18] do not take into account other imperfections in the surrounding material that may also impact the residual stress (e.g., weld beads that fill in base material, grindouts of the welds, different attachment configurations, etc.). Also through-wall cracks were introduced into the residual stress zone, rather than allowing a crack to initiate at the interior surface and grow. The actual crack growth may have re-distributed the residual stress and therefore the results of the model are not expected to be exact. Thus, although the general residual stress distribution modeled for these weld configurations is probably representative of the tanks, the exact lengths of the residual stress zones and K-solutions cracks may not be completely representative. A brief summary of these results is presented below.

\subsubsection{Vertical and Horizontal Seam Welds [16]}

Welding procedure specifications utilized to construct the Type II tanks were employed in the model development for seam welds. Seam welds consist of a total of 6 passes, with 3 passes deposited on the interior of the bevel groove and 3 deposited on the exterior of the groove. A summary of the key conclusions is presented below.

- Tensile transverse stresses are present at both the interior and exterior surfaces of the weld (see Figure 8). The tensile stresses at the interior surface are larger than those at the exterior surface. The tensile stresses at the interior surface are at a maximum approximately 0.25 inches from the weld centerline (40 ksi), while they are at a maximum slightly away from the fusion line on the exterior surface. At mid-plate, the residual stresses are in compression, which would hinder crack growth. Thus, throughwall cracks parallel to the weld, in the absence of attachments or repairs, would not be expected.

- The longitudinal stresses are predominantly tensile throughout the plate, except for a small section within the weld that is compressive (see Figure 9). The peak longitudinal stress on both the interior and exterior surfaces is approximately $62 \mathrm{ksi}$. The stresses are short range as it is estimated that they decay significantly approximately 0.5 inches from the weld centerline.

- $\quad$ The $\mathrm{K}$ values for a crack perpendicular to the weld, as a function of crack size, are shown in Table 3. As the crack size increases, the $\mathrm{K}$ values decrease as the residual stresses are relieved and redistributed. The $\mathrm{K}$ values for cracks less than 1 inch are greater than $\mathrm{K}_{\mathrm{Iscc}}$ through-out the plate thickness. This result indicates that the initiation of cracks perpendicular to the weld is favored. It is interesting to note that $\mathrm{K}$ still remains relatively high even though the residual stresses at the crack front are negligible for cracks up to 2 inches in total length. This result is due to the re-distribution of the longitudinal stress that occurs with the presence of a crack. 


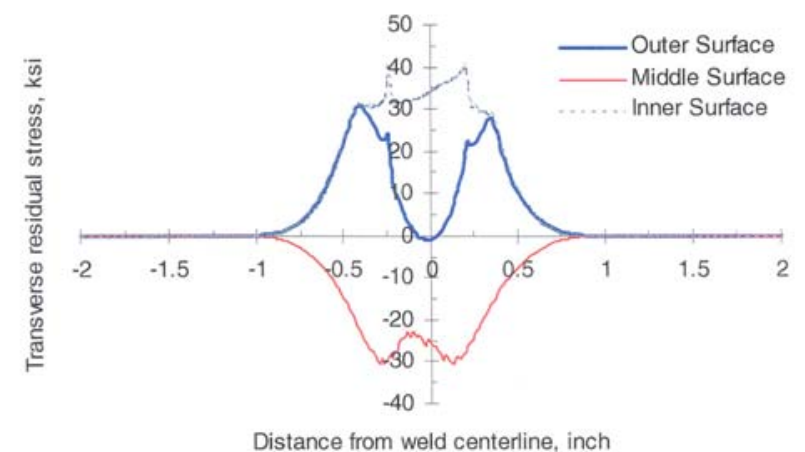

Figure 8. Tensile transverse residual stress at a seam weld [16].

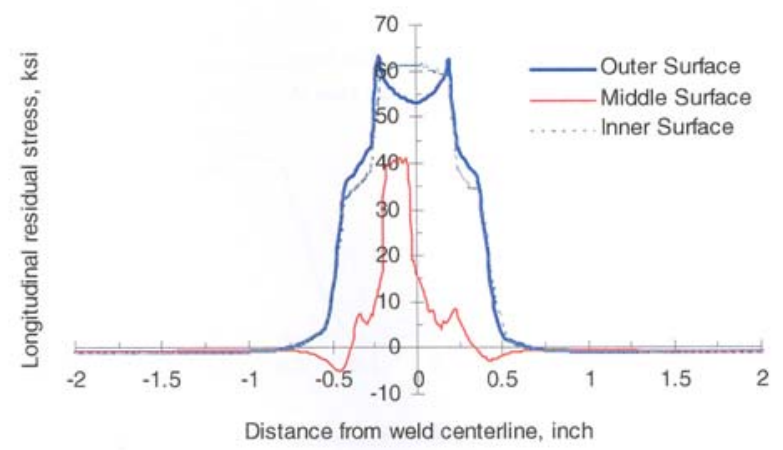

Figure 9. Tensile longitudinal residual stress at a seam weld [16].

Table 3. Stress intensity factors for transverse cracks driven by longitudinal residual stress [16].

\begin{tabular}{|c|c|c|c|}
\hline \multirow{2}{*}{$\begin{array}{c}\text { Crack Size (2a) } \\
\text { (inch) }\end{array}$} & \multicolumn{3}{|c|}{$\begin{array}{c}\text { Stress Intensity Factors (K) } \\
\left(\mathrm{ksi} \mathrm{in}^{1 / 2}\right)\end{array}$} \\
\cline { 2 - 4 } & Interior & Mid-plate & Exterior \\
\hline 0.4 & 46.89 & 31.97 & 47.73 \\
\hline 1 & 35.03 & 34.07 & 38.22 \\
\hline 2 & 19.48 & 19.60 & 20.30 \\
\hline 4 & 9.69 & 9.92 & 9.83 \\
\hline 6 & 7.45 & 7.67 & 7.46 \\
\hline 8 & 4.53 & 4.70 & 4.69 \\
\hline 10 & -4.60 & -4.91 & -5.21 \\
\hline
\end{tabular}

\subsubsection{Intersection of Horizontal and Vertical Seam Welds [17]}

The residual stress pattern at the intersection of a horizontal and vertical weld is complex due to the interactions of the two welds. Near the intersection, the longitudinal stress along the horizontal weld becomes the transverse stress component perpendicular to the vertical weld, and vice versa. The model assumed that the horizontal weld was performed first, followed by the vertical weld. Previous studies have shown that the last weld made dominates the characteristics of the intersection area. A summary of the key results is presented below. 
- The results showed that within 2 inches of the intersection significant changes in the residual stress distribution occurs. The longitudinal stress at the horizontal weld is significantly reduced due to the introduction of the vertical weld (see Figures 10 and 11). In contrast the transverse residual stress component of the vertical weld dominates (i.e., tendency to open a vertical crack parallel to the weld).

- A "pocket" of residual stress exists a couple of inches below the horizontal weld and parallel to the vertical weld where the transverse residual stresses increase significantly (see Figures 10 and 12). These stresses would tend to open a crack that was parallel to the vertical weld. However, the transverse stress in the middle of the plate remains in compression and therefore the crack is not predicted to go through-wall.

- For a crack assumed to initiate from the weld intersection and propagate parallel to the vertical weld, the $\mathrm{K}$ values at the crack tip increase as the crack grows to 2 inches. This gradually decreases as the crack size increases past this length.

- For short horizontal cracks near the fusion line of the horizontal weld, the $\mathrm{K}$ values are greater than $\mathrm{K}_{\mathrm{Iscc}}$ at the interior and exterior surfaces. The $\mathrm{K}$ value decreases rapidly as crack size increases. The mid-plate values for $\mathrm{K}$ are less than $\mathrm{K}_{\text {Iscc }}$, and therefore part through-wall cracks are more likely.

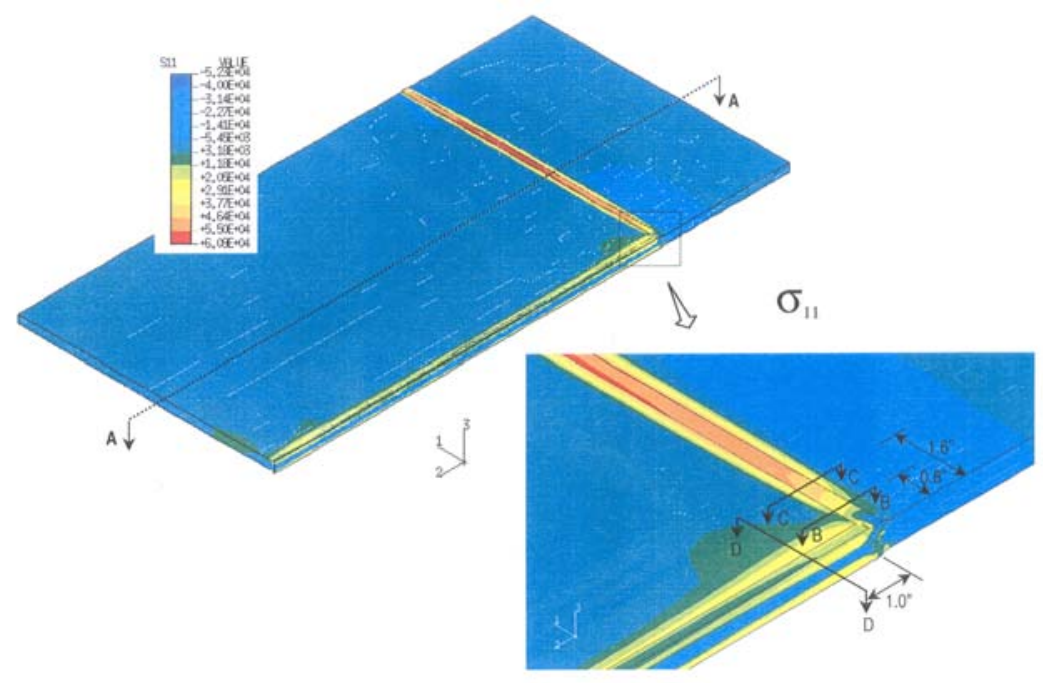

Figure 10. Contour plot of longitudinal stress distribution at the horizontal weld and transverse stress at the vertical weld. Horizontal weld is indicated by cross-sections B-B and C-C, while the vertical weld is indicated by cross-section D-D [17].

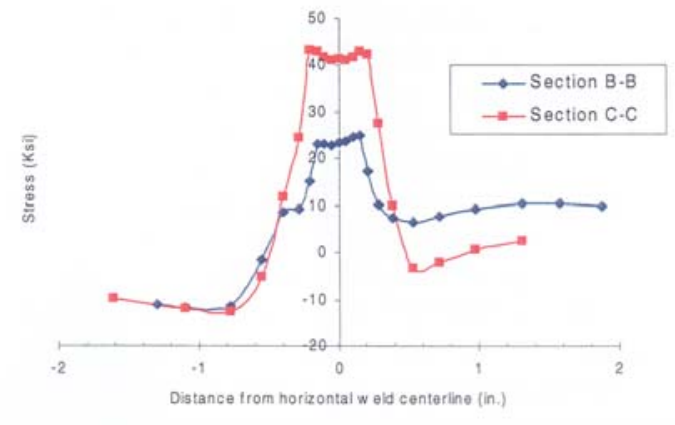

Figure 11. Magnitude of longitudinal residual stress at the horizontal weld at sections B-B and C-C [17]. 


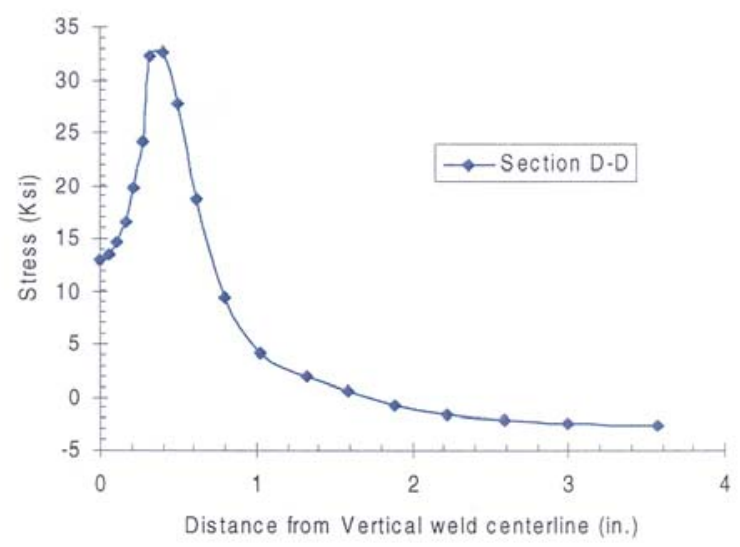

Figure 12. Magnitude of transverse residual stress at the vertical weld at section D-D [17].

\subsubsection{Repair Welds [18]}

Analytical and experimental studies have shown that repair welds often exhibit significantly higher residual stresses than the original weld. Weld repair is usually performed locally under a higher degree of constraint than the original welding. The residual stresses due to the repair weld were investigated as a function of the length, the depth, and the width of the repair weld. The K values for cracks parallel and perpendicular to the repair weld were also modeled. Some key observations were:

- High tensile transverse residual stresses occur perpendicular to the repair weld fusion line, extending beyond the heat affected zone on the exterior surface (see Figure 13) and the interior surface. Figure 13 shows a narrow repair weld (i.e., width of the repair weld is approximately equal to the original weld). These residual stresses would tend to drive cracks that are parallel to the repair weld. At the repair weld fusion line, the residual stresses on the interior surface and exterior surfaces are tensile (Note: The magnitude of the stresses on the interior is slightly greater than that on the exterior.). However, the large compressive stresses in the mid-thickness region of the plate would prevent growth of through-wall cracks near the repair weld fusion line. Away from the repair weld fusion line, the residual stresses at both the interior and exterior are still tensile, however, they are slightly lower in magnitude (Note: The magnitude of the stresses on the exterior is slightly greater than that on the interior). However, the residual stresses at the mid-thickness region of the plate are also tensile. Thus, through-wall tensile stresses parallel to the repair weld occur a short distance away from the repair weld fusion line.

- The width of the repair weld has a significant effect on the transverse residual stress distribution. Wider repair welds (i.e., the repair weld is at least two times the width of the original weld) produce tensile stresses over a greater distance from the weld center-line on the exterior surface than narrow repair welds (see Figure 14). However, on the interior surface, a short distance from the repair weld fusion line, a large region of transverse compressive residual stress exists (see blue area on Figure 15). Therefore, for wide repair welds the through-wall tensile residual stresses reside very close to the repair weld fusion line.

- The width of the repair also has a significant impact on the stress intensity factors of cracks parallel to the weld. For narrow repairs, the K values are such that through-wall cracks parallel to the repair weld are expected to grow a short distance from the repair weld fusion line. Partial through-wall cracks may initiate on the interior surface near the weld fusion line, however, due to the compressive residual stresses in the mid-thickness region of the plate, through-wall cracks would be not expected at this location. 
- For wider repair welds, the compressive residual stresses on the interior surface would prevent the initiation of cracks a short distance from the weld. However, the $\mathrm{K}$ values within a narrow band near the repair weld fusion line are positive through-wall and therefore could result in crack growth at this location. Figure 7 shows an example of a wide repair weld where the crack propagated near the repair weld fusion line.

- $\quad$ Based on the $\mathrm{K}$ value results, the model indicates that repair weld residual stress effects become negligible if the crack becomes larger than three times the repair length.

- The depth of the repair weld appears to have little effect on the residual stress distribution.

- For perpendicular cracks K follows a similar trend to that observed for the original seam weld, only higher in magnitude.
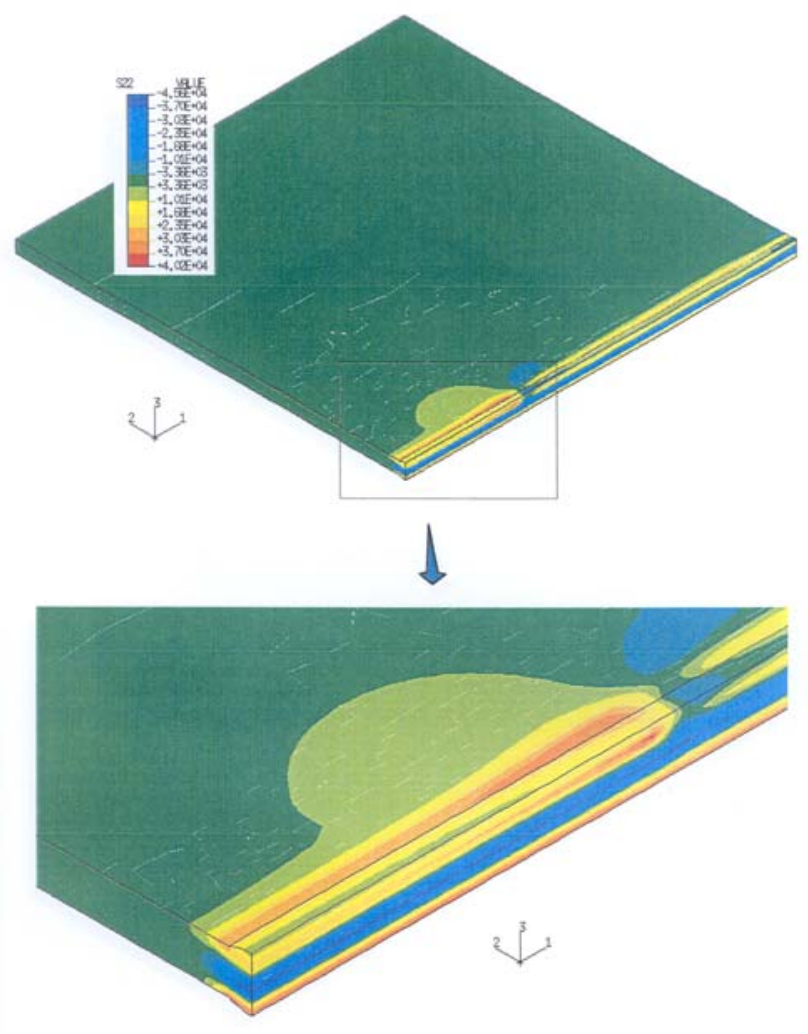

Figure 13. Transverse residual stress distribution after repair [18]. 


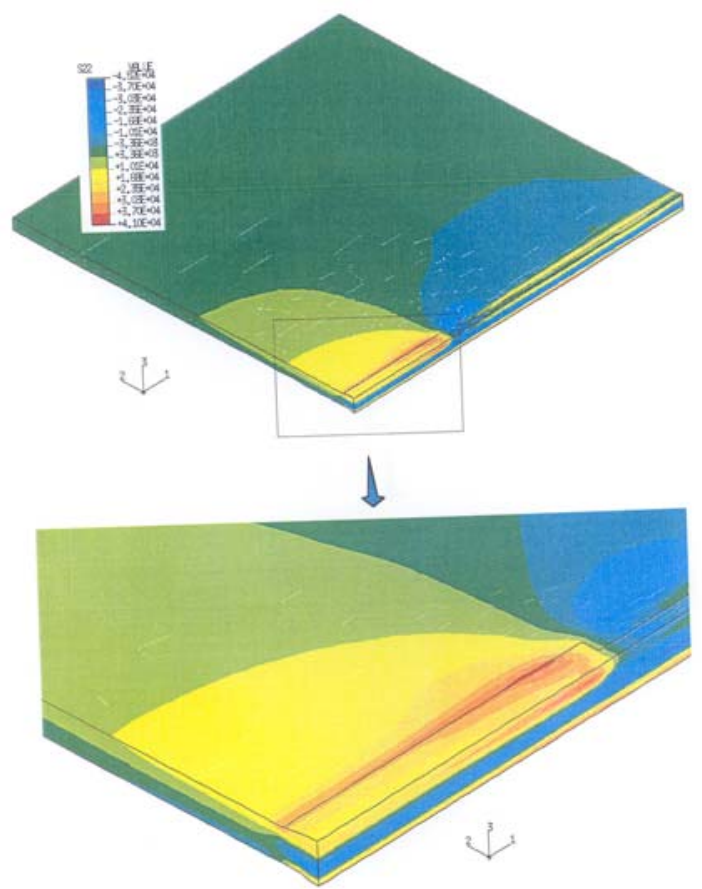

Figure 14. Effect of width of repair on the transverse residual stress distribution. The exterior surface is shown in the figure [18].

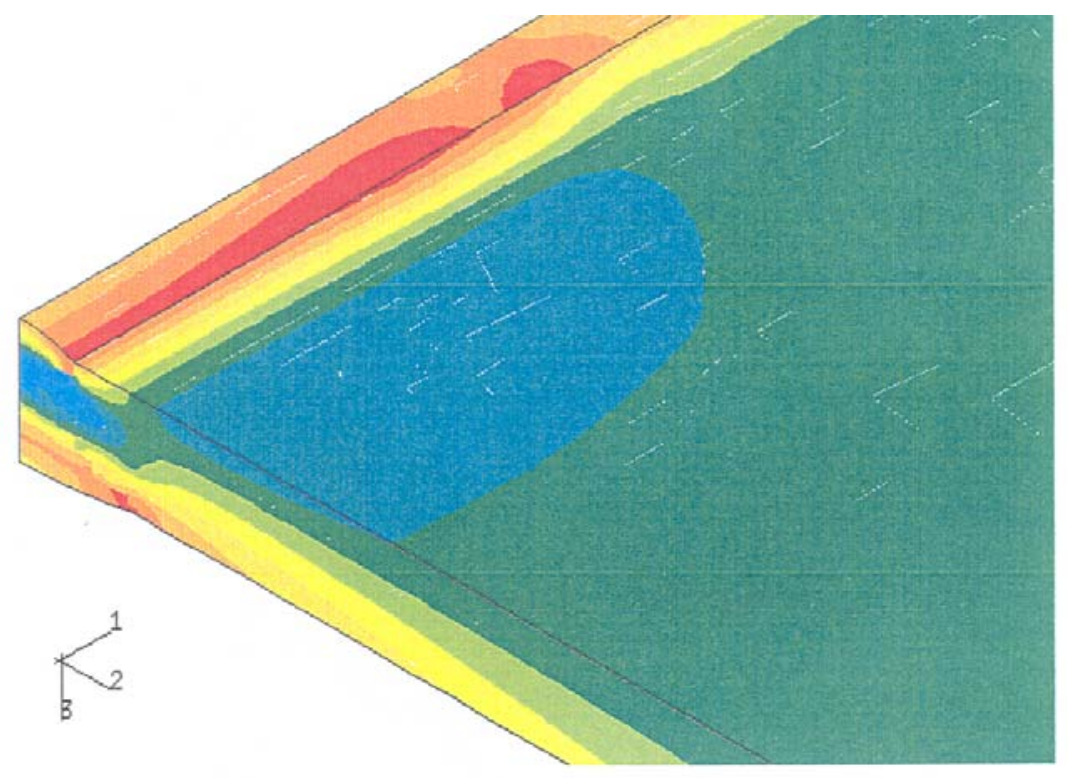

Figure 15. Effect of width of repair on the transverse residual stress distribution. The interior surface is shown in the figure [18]. 


\subsubsection{Attachment Welds [17]}

For modeling purposes, an attachment (a 6 by 4 by 3/8 inch plate) was joined to the base metal with a Tfillet weld. It was then assumed that the plate and the attachment weld were machined off the surface. Preservice inspections indicate that removal of attachment welds in the tanks was not always performed. Additionally, attachments were in a variety of configurations and locations in the tanks, which would affect the stress distribution. A brief summary of the key observations is presented below.

- $\quad$ The transverse residual stress for an attachment weld is of a bending type. The stress on the exterior surface is tensile, while that on the interior the stress is slightly compressive.

- The longitudinal stress is tensile throughout the thickness of the shell for the attachment weld. The maximum stress occurs on the exterior surface within the weld area (see Figure 16).

- $\quad$ K solutions for cracks parallel to the weld fusion line were developed. The K values were dominated by the local bending type of residual stresses.
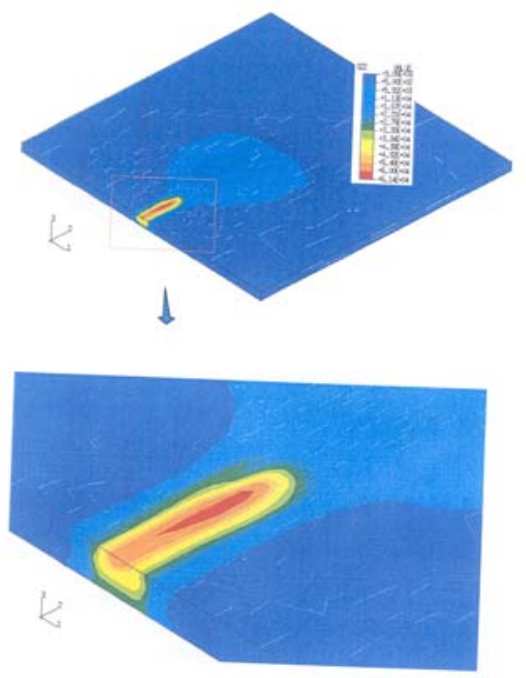

Figure 16. Longitudinal residual stress distribution near an attachment weld [17].

\subsection{Analysis of Crack Data From Recent Ultrasonic Inspection}

The ten cracks that were identified during a UT inspection performed in 2002 [2] were re-examined in 2007 [3]. During this re-examination, one indication that was initially reported as a "possible perpendicular crack $<25 \%$ through wall”, was clearly shown not to be a crack. Additionally, examination of a new area immediately adjacent to other cracks along a vertical weld revealed three new cracks. It is not known when these new cracks formed as they could very well have been present in 2002 as well. Therefore, a total of twelve cracks were evaluated during the re-examination.

Of these twelve cracks, nine were located in the vapor space above the sludge layer, including the three new cracks. Comparison of the crack lengths measured in 2002 and 2007 revealed that crack growth had occurred in four of the six previously measured vapor space cracks. None of the three cracks beneath the sludge showed evidence of growth. Since insignificant growth had been anticipated, it will be useful to review how the cracks were sized and how growth was confirmed.

The inspection was performed with the FORCE Technology, P-scan, PS4-Lite, automated, ultrasonic system. This system is capable of operating 2 angle beam and 1 thickness mapping transducer or 4 angle beam probes simultaneously. The PS4-Lite also controls the wall crawler that carries the probes across the tank surface. The crawler was also built by FORCE Technology and attaches to the steel tank wall by 
strong permanent magnetic wheels. The crawler is also outfitted with a remote control pan and tilt camera system with auxiliary lighting. Crack detection was performed utilizing single element, 45 degree shear wave transducers (Krautkramer MWB-45-4E) operating at $4 \mathrm{MHz}$.

The location and length/width in the $\mathrm{X}$ and $\mathrm{Y}$ directions were determined based on where the indication was discernable from the background noise or thickness. Crack lengths were reported to the point(s) where the indication was no longer discernable from the noise (See Figure 17). If a crack was branched, the crack tips that resulted in the maximum length in the vertical or horizontal orientation were utilized. No attempt was made to estimate the length along an arc. Crack depths were determined utilizing planar flaw sizing techniques. For indications less than 100\% through-wall, the Absolute Arrival Time Technique was used to measure the remaining metal ligament.

Although the techniques and the transducers used to size the crack in 2002 and 2007 were the same, there was a significant mechanical improvement to the fixtures that held the probes. This improvement allowed for better contact between the probe and the tank wall surface and a closer approach to the seam weld bead. As a result, better scan resolution, and hence more accurate sizing, was achieved. For example, the difference in resolution, and the effect on sizing, is clearly shown in Figure 17. In 2002, this crack was sized by starting at the tip on the upper plate and driving the crawler over the weld and then locating the crack closest to the vertical weld. In the process of driving over the weld, probe contact was lost approximately 1" from the horizontal weld and therefore you have no signal in this area. As it crossed the weld bead, the wheels on the crawler may have spun a little adding additional length to the crack measurement. Thus, the fact that the length that was reported in 2002 as "may be 10.7 inches combined", while in 2007 it was reported as 10.5" are not inconsistent. In 2007, with the new fixtures, scan was at a much higher resolution. For this scan, the crawler began above the tip of the crack in the upper plate and scanned across the horizontal weld then continued on the other side. The area missed due to the weld geometry was 1.8 to 2 inches. The improved resolution can be observed by comparing the two additional indications that were observed more clearly. In 2007, the scan was able show more clearly an additional indication adjacent to the vertical weld on the bottom plate. This is believed to be a weld bead on the interior surface of the tank wall. Additionally the scan in 2007 shows a crack branch that goes away from the weld. It could not be determined if this branch was present in 2002, or not.

To determine whether growth had occurred in this situation, the edge of the weld bead on the interior surface of the tank was used as a reference point. A comparison was then made between the distance between this reference point and the tip of the crack in 2002 and 2007. From this comparison it was determined that the tip of the crack had extended by 0.25 ”. Crack growth in the other three cases was determined similarly by comparing to reference points that were clearly observed in both 2002 and 2007. All available scan data was utilized to look for landmarks and determine if growth had occurred. Typically there were at least two sets of data for each indication from each examination period. 


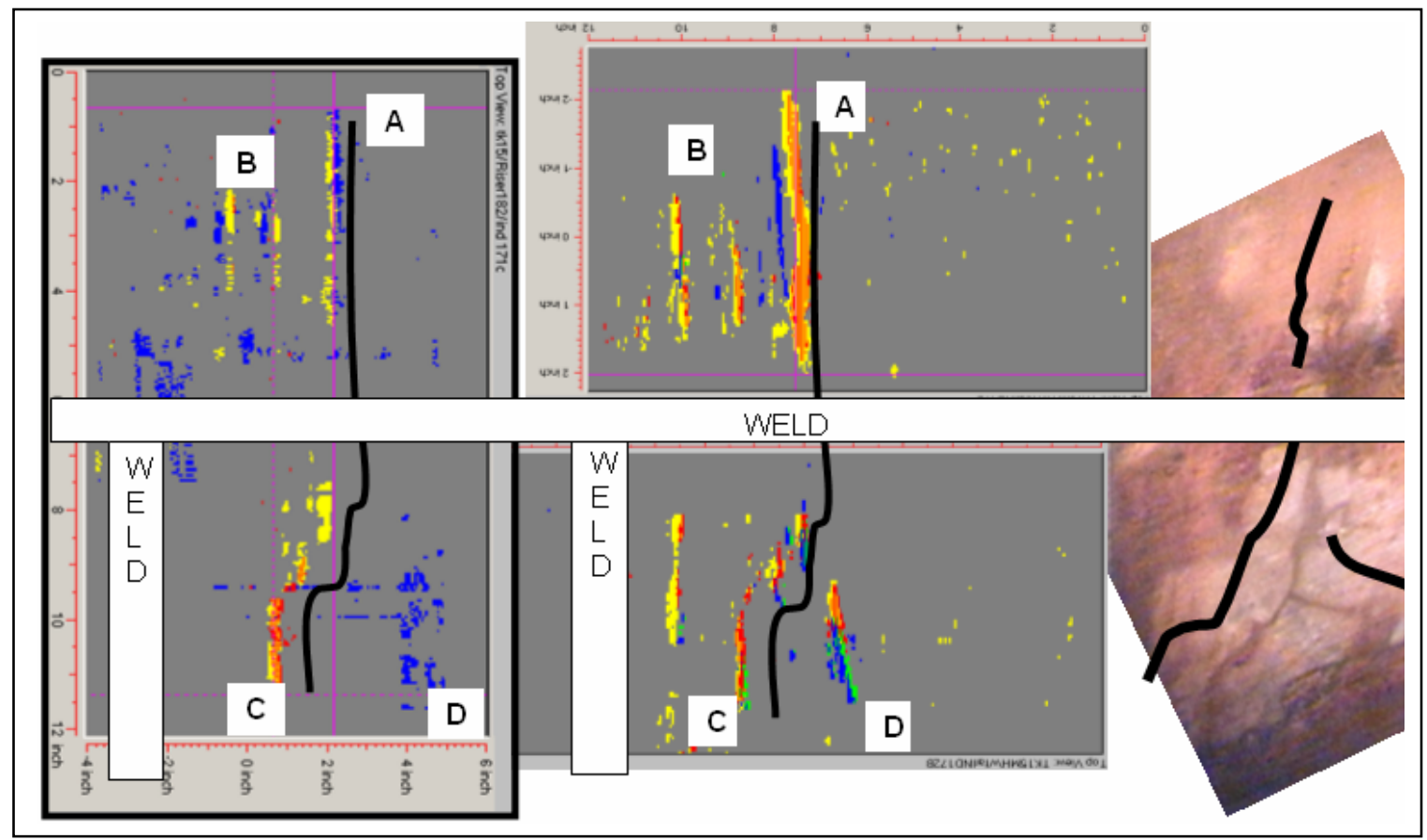

Figure 17. Images from crack \# 32002 (left) and 2007 (center and right)

As with the initial revision to this report [21], rudimentary drawings of the cracks as they might appear from the exterior of the primary tank wall are presented (e.g., Figure 18). Through-wall cracks were indicated by the red segments (these portions were also visible), while the partial through-wall segment were in blue. If crack growth was observed, two sketches are presented in the figure so that a comparison may be made. Segments of the cracks that were not inspected with UT, but could still be observed visually were also noted in purple. Visual observation of a crack was frequently possible by wetting the surface around the site with water. After waiting for the surface to dry, there was a short period of time where capillary forces resulted in water "bleeding" out from the site. The photograph in the figure above shows the crack using this "bleedout" technique. Table A1 in the Appendix provides additional data on the location, size, and orientation of each individual crack, and its historic service environment.

A three inch reference zone, shown in green, around the weld was utilized to assess the cracks. This reference zone is based on the 6- inch reference crack [6] that was observed across the weld by the dye penetrant tests on Tank 16. The length was consistent with literature residual stress analysis at the time of the penetrant tests and also the more recent Battelle residual stress results [16-18]. It should be noted however, that this distance is not precise and variations in the distance from the weld from 3 to 5 inches could occur depending on the how the material was welded in the field.

An analysis of each crack was performed. The characteristics of a crack were compared with known models for stress corrosion cracking or previous observations of stress corrosion cracks. An assessment of the impact of the crack on structural stability (i.e., flaw instability) was also determined.

\subsection{Crack \#1}

The rudimentary drawing of crack \#1 is shown in Figure 18. The crack was first visually observed in 1998 due to moisture leaching from the interior to the exterior and had no associated leakage. UT inspections of this crack were performed in 2002 and 2007. During the first 21 years of service the crack was exposed to supernate, while for the past 25 years it has been in the vapor space. Though the exact date is unknown, visual inspection results and the limited amount of leakage appear to indicate that through-wall penetration occurred during the past 25 years of vapor exposure. Initiation of the crack may have occurred during the exposure to supernate. 

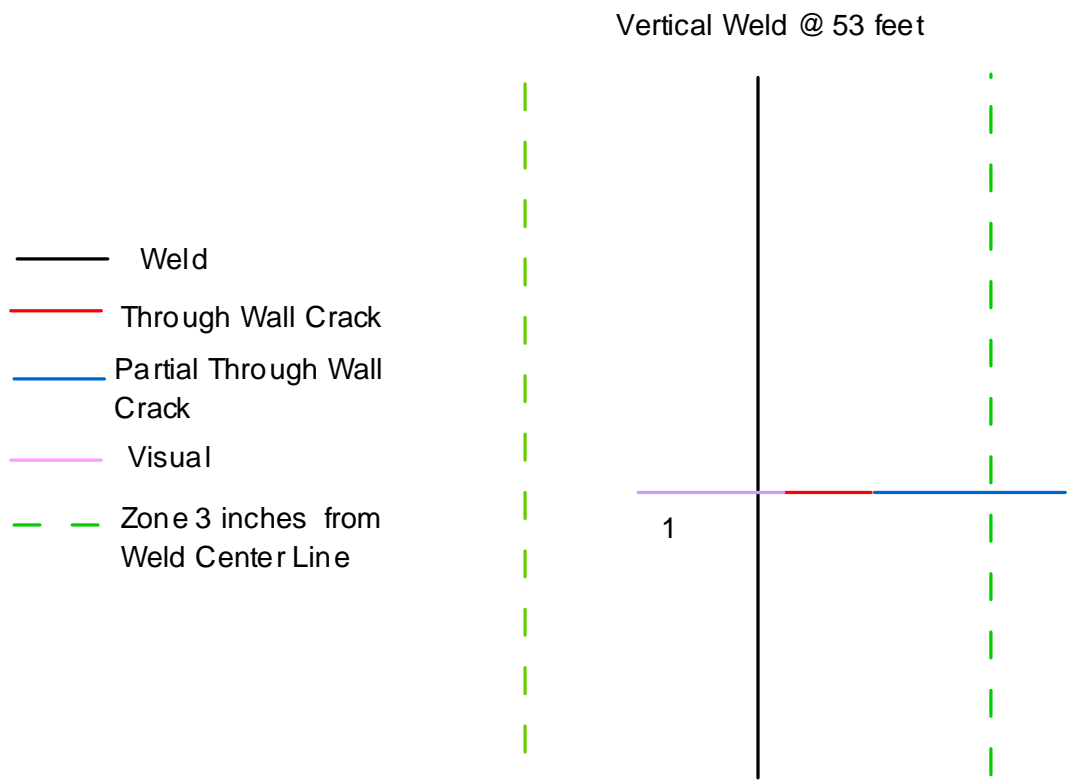

(a)
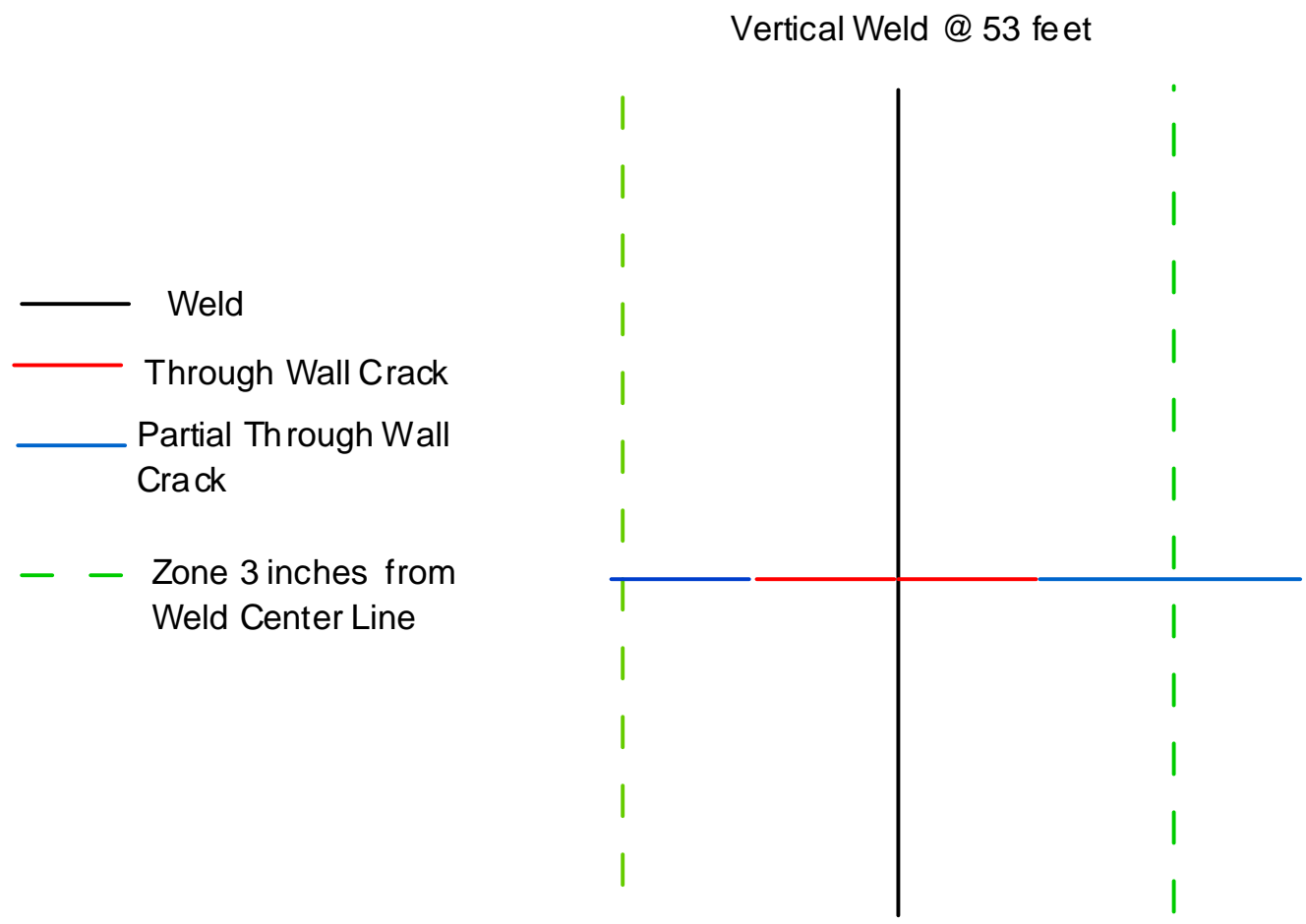

(b)

Figure 18. Rudimentary drawing showing crack \# 1 (a) 2002 and (b) 2007. 
The UT inspection in 2002 was performed on the portion of the crack to the right of a vertical weld. Visual inspections at the time indicated that the crack extends through the weld to the other side. The throughwall portion of the crack extends approximately 1.4 inches from the weld center-line and is roughly perpendicular to the vertical weld (i.e., horizontal). However, the UT inspection revealed that the crack extends an additional 2.9 inches part through-wall. The crack length of 4.3 inches to the right of the weld extends slightly beyond the assumed 3-inch residual stress zone around the weld. The data from the UT scan are portrayed in Figure 19. In 2002 (top image in Figure 19), only the right side of the crack was scanned. The images in Figure 19 are from the right side of the indication, from 2002 (top) and 2007 (bottom). The images would need to be flipped to coincide with the photograph of the indication. The growth is evident on the left side of the image.

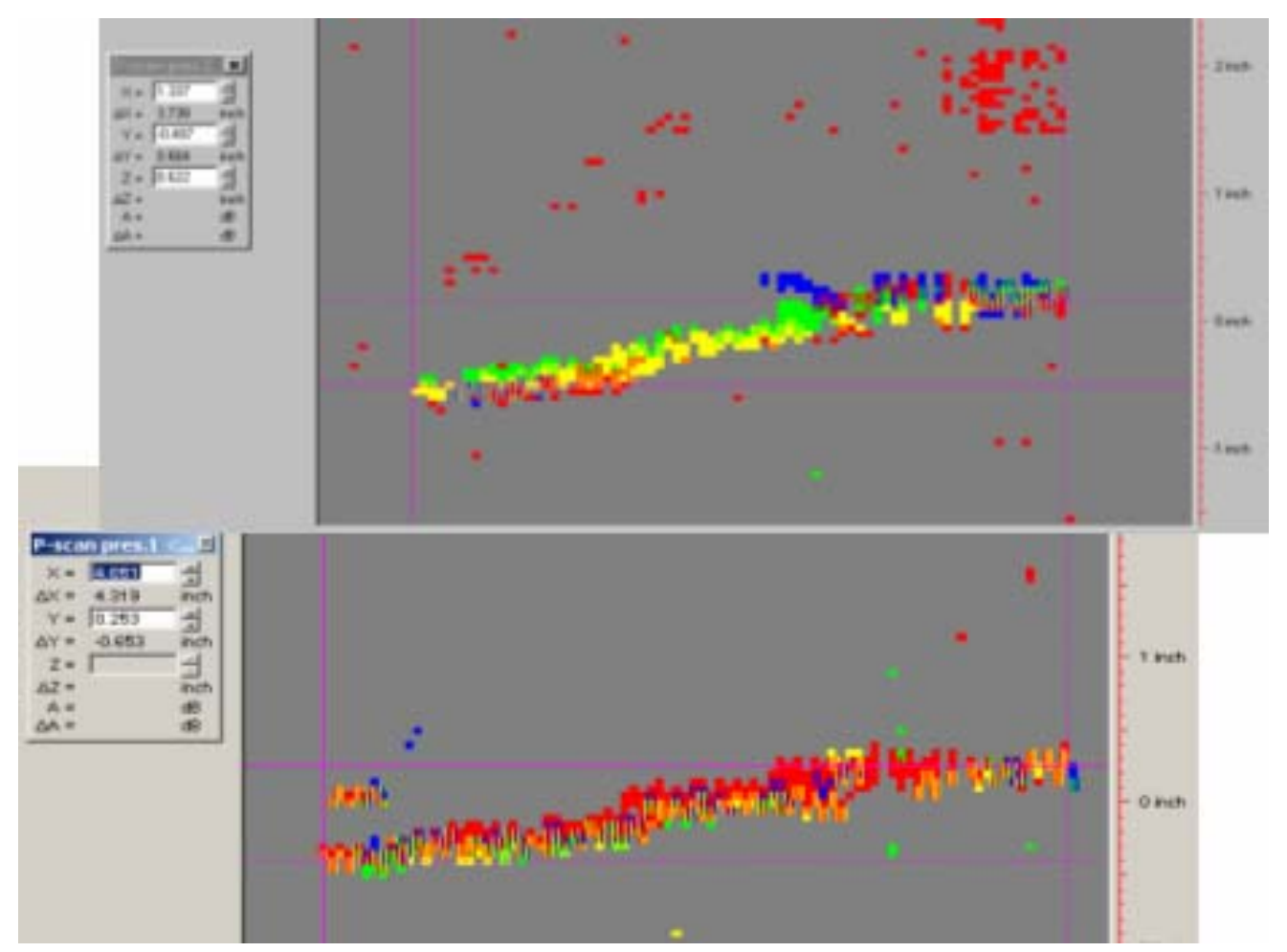

Figure 19. UT data from Crack \#1 demonstrating crack growth measurement.

The measured growth was 0.46 inches. The UT scan indicates that this crack extension is approximately $20 \%$ through-wall. The fact that the crack did not proceed through-wall indicates that the residual stresses, and hence the driving force for crack growth, has decreased.

The crack on the left hand side of the weld was not measured in 2002, however, there was visual evidence of the crack. This segment of the crack is approximately 3.4 inches long, therefore it extends to the edge of the residual stress zone. The through-wall portion of the crack on the left hand side of the vertical weld appears to be approximately the same length as that on the right hand side, and the partial through-wall segments are approximately the same as well.

Due to a lack of significant driving forces, either hydrostatic or residual stresses, the crack currently does not impact either the structural stability or the leak tightness of the tank. At this time the level the tank will be at during waste removal is not known, thus the crack may or may not be exposed to liquid again. However, it is not expected that this crack will grow during this time even if the waste is raised above this level. The relatively high location of the crack would minimize the hydrostatic stresses during waste 
removal should the waste exceed this level. In addition the waste will likely have a relatively low specific gravity. Therefore, from a structural stability perspective the crack is not anticipated to be significant. If the waste is raised above this level, leakage may occur. Procedures to handle the leakage are in place.

\subsection{Crack \#2}

The rudimentary drawing of crack \#2 is shown in Figure 20. The leak site was first observed in 1973 and a salt deposit remained until the UT inspection. Between 1961 to 1968 the site was exposed primarily to supernate. As the sludge level in the tank increased, the site was located at approximately the sludge liquid interface between 1968 to 1978. The site was completely immersed in sludge from 1978 to 1982, after the tank received a sludge transfer from Tank 16. Between 1982 to 1989, the site was exposed to residual supernate from the waste removal operations. Since 1989 the site has been in the vapor space. The exact date of through-wall penetration is unknown, however, visual observations suggest that it occurred either during exposure to the supernate or the sludge layer.

The crack was located in the center of the lower shell plate far removed from seam welds. There is visual evidence that the crack is associated with a weld attachment. Previously, mid-plate leak sites were also correlated with weld attachments (see Tank 16 and Tank 6). The arc-like nature of the crack is also consistent with results observed during laboratory testing [15]. The visually observed portion of the crack is parallel to a weld fusion line. The portion that was inspected with UT shows the influence of the intersection of two fillet welds on the residual stress distribution. Curvature is generally the result of a region of large compressive stresses that exist at the end of these regions. The total length of the crack could not be measured due to the weld attachment obstruction. In 2002, the portion of the crack that was measured was approximately 3.7 inches in the vertical direction and 2.3 inches in the horizontal direction. No mention was made as to whether the crack was longer on the interior or exterior of the tank. If the visually observed portion of the crack were estimated to be approximately 2 inches longer, the total length of the crack would be approximately 6 inches. The UT examination performed in 2007 indicated no changes in the crack length.

Due to a lack of significant driving forces, either hydrostatic or residual stresses, the crack currently does not impact either the structural stability or the leak tightness of the tank. At this time the level the tank will be at during waste removal is not known, however, this site is close enough to the sludge level that it is very likely that waste will be above the crack during waste removal. The primarily vertical characteristics of the crack would be subject to hydrostatic stresses in the hoop direction. The hydrostatic stresses are potentially higher at this site than for Crack \#1, however, it is anticipated that the sludge slurry during waste removal would have a relatively low specific gravity of the sludge slurry. Therefore, from a structural stability perspective the crack is not anticipated to be significant. If the waste is raised above this level, leakage may occur. Procedures to handle the leakage are in place. 


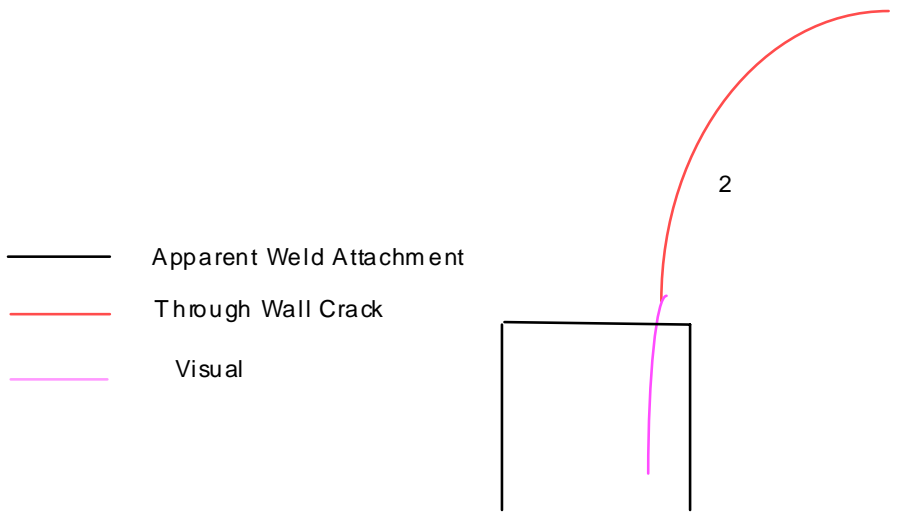

Figure 20. Rudimentary drawing showing crack \#2.

\subsection{Crack \#3}

The rudimentary drawing of crack \#3 is shown in Figure 21. Since this crack is part through-wall, there was no previous indication of a crack. Between 1961 to 1965 the site was exposed primarily to supernate. The site has been completely immersed in the sludge since that time. The exact date of crack initiation is unknown, however, it is apparent that it occurred either during exposure to the supernate or the sludge layer.

The crack is vertical and was located approximately 0.8 " above the bottom horizontal weld. In 2007, the crack was approximately $25 \%$ through-wall and 0.6 inches long. Although, the length was slightly longer than that measured in 2002 (i.e., 0.55 inches), comparison of the two UT scans did not provide sufficient evidence to suggest that any crack growth had occurred. Due to a lack of significant driving forces, either hydrostatic or residual stresses, and the fact that the crack is part through-wall the crack currently does not impact either the structural stability or the leak tightness of the tank. Since the crack is within the 3-inch reference zone around the weld, future crack growth is possible. However, maintaining the waste within the corrosion control limits during any future waste removal operations would minimize this possibility.

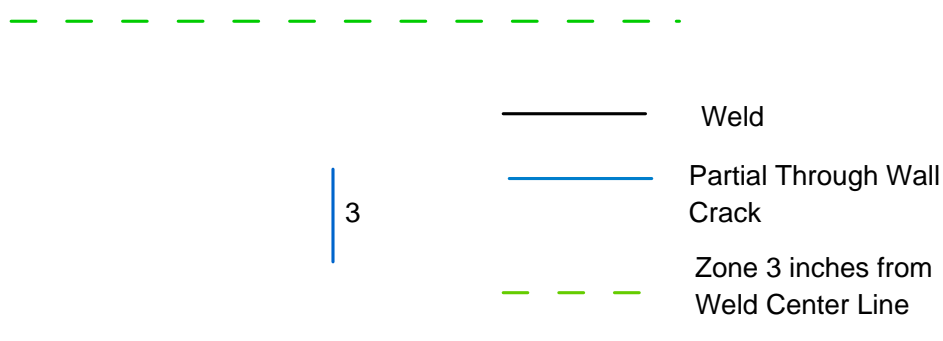

Lower Girth Weld @ 30 inches

Figure 21. Rudimentary drawing of crack \# 3. 


\subsection{Crack \#4}

The rudimentary drawing of crack \#4 is shown in Figure 22. The leak site was first observed in 1973 and a salt deposit remained until the UT inspection. Between 1961 to 1982 the site was exposed primarily to supernate. Since that time, the site has been exclusively in the vapor space. The exact date of through-wall penetration is unknown, however, visual observations suggest that it occurred during exposure to the supernate.

The crack is located near the intersection of a vertical weld and the middle horizontal weld, and is roughly perpendicular to the horizontal weld. In 2007, the UT examination revealed that this vertical crack appears to consist of four segments, one through-wall crack (4a) and three smaller partial through-wall cracks (4b, 4c, and 4d). If segments 4a-4c are considered a single crack, the crack length would be approximately 10.5 inches. This crack is the longest vertical crack ever observed. The through-wall portion of crack 4a was approximately 7 inches, although on the interior the crack was approximately 7.9 inches. In 2007, it was determined that the segment of crack $4 a$ in the upper plate had extended approximately 0.25 inches in the direction away from the weld, and therefore just outside the residual stress zone. The portion of the crack that extended was partial through-wall. The three other sections of the crack were approximately $50 \%$ through-wall and were $1.0(4 \mathrm{~b})$ and $1.8(4 \mathrm{c})$, and 1.4 (4d) inches long. No extension was observed for cracks $4 \mathrm{~b}$ and 4c. Crack segment $4 \mathrm{~d}$ was not observed in 2002. Due to the improvements in the probe fixtures it is not known whether this crack segment was actually present in 2002. In addition to the intersection of the vertical and horizontal seam welds, weld beads in the vicinity of the crack may have influenced the residual stress distribution. However, assuming they are cracks, both were outside the 3 inch zone around the horizontal weld, but within the 3 inch zone of the vertical weld. Residual stress modeling of a region near a horizontal and vertical weld indicates that a "pocket" of tensile stress in the direction transverse to the vertical weld is present approximately at the location of Cracks 4b, 4c, and 4d (see Figure 10). Thus, the cracks would tend to grow parallel to the vertical weld rather than perpendicular. The modeling also suggests that this tensile stress has a relatively short range and therefore the crack driving force in that direction decreases. After this short distance, the primary tensile stress becomes longitudinal to the vertical weld.

Due to a lack of significant driving forces, either hydrostatic or residual stresses, the crack currently does not impact either the structural stability or the leak tightness of the tank. At this time the level the tank will be at during waste removal is not known. However, if the waste level were to exceed the middle horizontal weld, the primarily vertical characteristics of the crack would be subject to hydrostatic stresses in the hoop direction. The hydrostatic stresses are potentially higher at this site than for Crack \#1, however, it is anticipated that the sludge slurry during waste removal would have a relatively low specific gravity of the sludge slurry. The instability length for a vertical crack at the middle girth weld of a Type I tank, with a solution with specific gravity of 1.1, was estimated to be 111 inches for normal operating conditions and 64 inches for seismic conditions [22]. Although, this is a Type II tank rather than a Type I, there are enough similarities between the two tank styles that one may assume that the instability crack length would be similar. Therefore, from a structural stability perspective the crack is not anticipated to be significant. If the waste is raised above this level, leakage may occur. Procedures to handle the leakage are in place. 


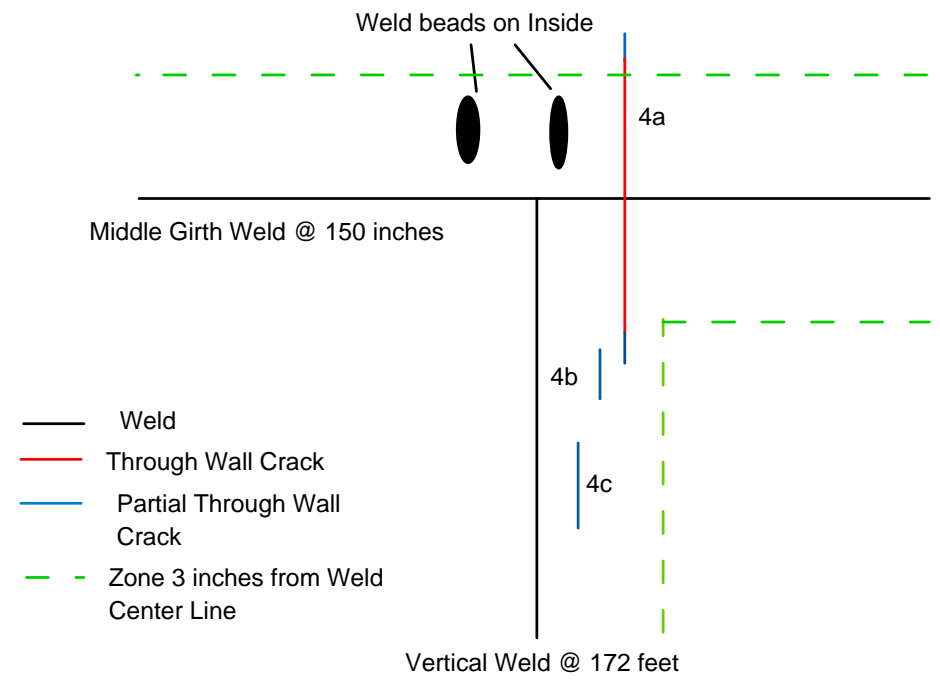

(a)

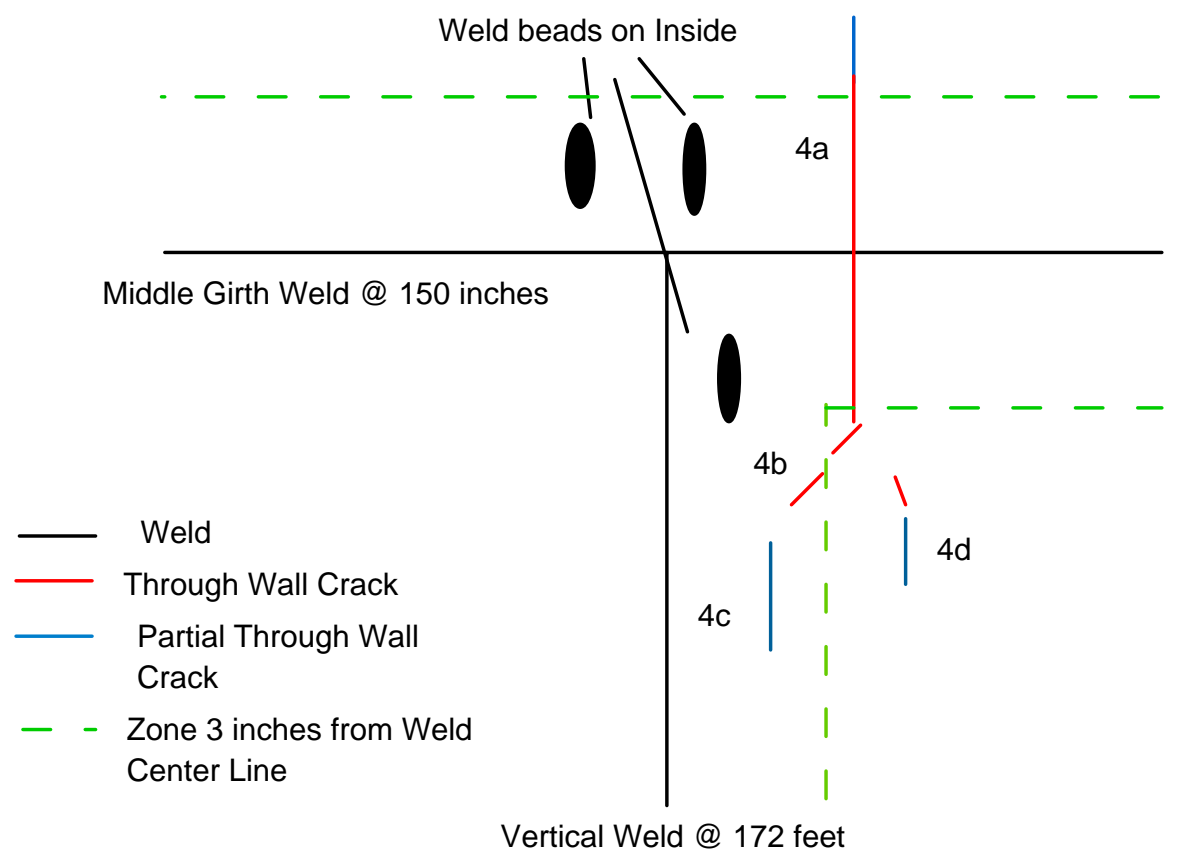

(b)

Figure 22. Rudimentary drawing of crack \#4 (a) 2002 and (b) 2007.

\subsection{Crack \#5}

The rudimentary drawing of crack \#5 is shown in Figure 23. The crack was first observed in 1998 and had only a limited amount of leakage. During the first 21 years of service the crack was exposed to supernate, while for the past 25 years it has been in the vapor space. Though the exact date is unknown, visual inspection results and the limited amount of leakage appear to indicate that through-wall penetration 
occurred during the past 25 years of vapor exposure. Initiation of the crack may have occurred during the exposure to supernate.

The crack is located near a repair weld in the middle horizontal weld. The crack arcs slightly around the repair weld, however it is primarily oriented in the horizontal direction. In 2007, the length of the crack was determined to be approximately 20 inches. In 2002, the crack was reported to be approximately 18 inches. However, comparison of the two scans indicated that there was actually no further growth. The through-wall portion of Crack 5 is approximately 10 inches and is in the section of the crack that is adjacent to the repair weld. At each end of the through-wall section of the crack are part through-wall sections. The crack to the left of the repair is approximately 6 inches and appears to branch, while the portion of the crack to the right is approximately 4 inches. The arc-like pattern of the crack adjacent to the weld repair is consistent with laboratory results [15]. The behavior also agrees with the residual stress model for a narrow weld repair in that the crack is located a short distance from the weld repair fusion line. The simulated weld repairs in the laboratory were much wider than this repair in the tank. This crack is the longest ever observed.

Due to a lack of significant driving forces, either hydrostatic or residual stresses, the crack currently does not impact either the structural stability or the leak tightness of the tank. The fact that the crack is oriented primarily in the horizontal direction means that hydrostatic stresses in the hoop direction will not have a significant impact on further growth of this crack. Therefore, from a structural stability perspective the crack is not anticipated to be significant. If the waste is raised above this level, leakage may occur. Procedures to handle the leakage are in place.

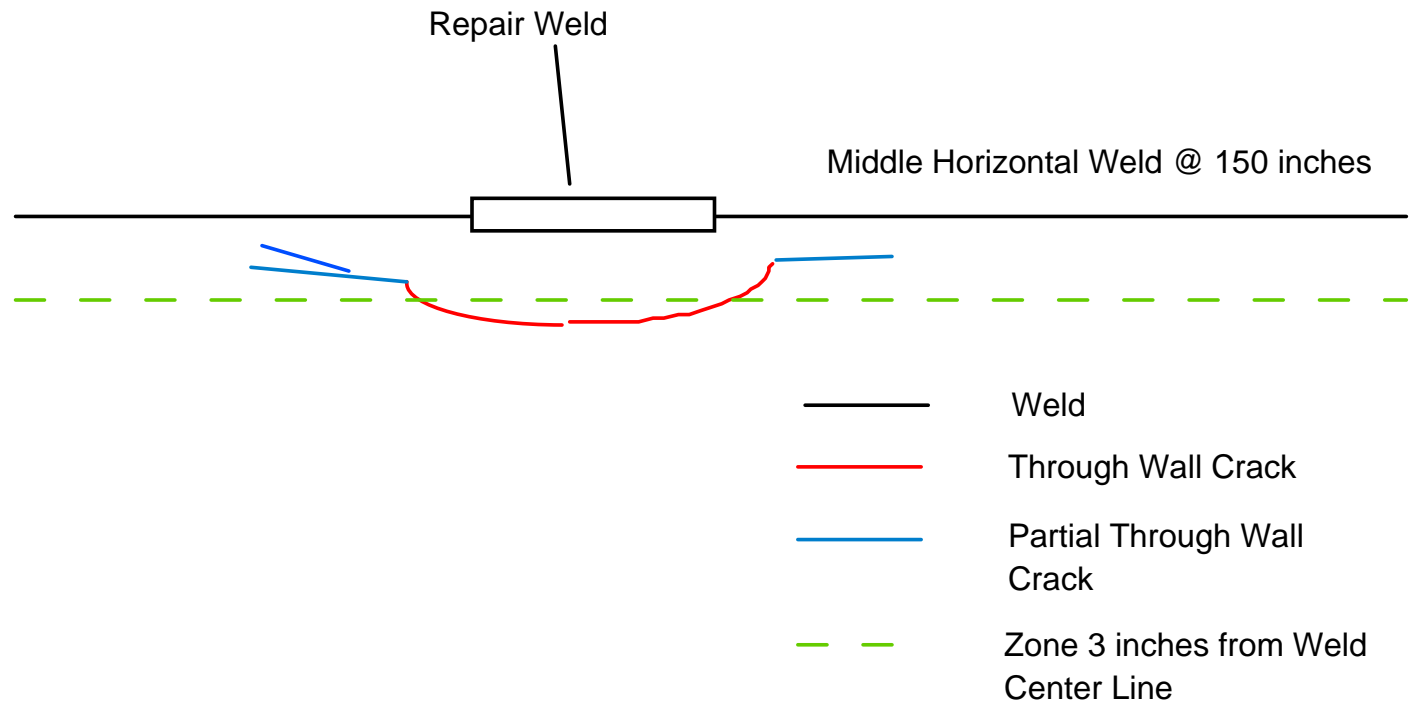

Figure 23. Rudimentary drawing of Crack \#5.

\subsection{Crack \#6}

The rudimentary drawing of crack \#6 is shown in Figure 24. The crack was first observed in 1994 and had only a limited amount of leakage [23]. During the first 21 years of service the crack was exposed to supernate, while for the past 25 years it has been in the vapor space. Though the exact date is unknown, visual inspection results and the limited amount of leakage indicate that through-wall penetration occurred during the past 25 years of vapor exposure. Initiation of the crack may have occurred during the exposure to supernate. 
This crack has been the subject of several investigations [5]. The crack is located near a repair weld in the middle horizontal weld (see Figure 25). In 2007, it was determined that the length of the crack was approximately 19 inches. The visible portion of the crack begins at the left edge of the repair weld and then arcs so that it becomes parallel to the horizontal weld. According to the residual stress modeling, the maximum transverse tensile stress occurs at this location. The distance of the parallel portion of the arc is approximately 6 inches from the center of the weld. This distance is further than that observed for Crack \#5, however, the effect of a nearby vertical weld may influence the residual stress pattern as well. The through wall portion of the crack is approximately 14.4 inches. At each end of the through-wall section of the crack are part through-wall sections. In the plate above the weld, a primarily vertical branched crack extends tangentially from the repair weld approximately 3.7 inches above the middle horizontal weld. Approximately 1 inch of this segment is through-wall, whereas in 2002, all of this segment was part through-wall. There has been approximately 1.7 inches of crack extension into the base plate since 2002 . The segment that has extended is part through-wall. The part through-wall crack in the plate beneath the weld arcs back toward the middle horizontal weld. The arc-like pattern of the crack adjacent to the weld repair is consistent with laboratory results [15]. The behavior also agrees with the residual stress model for a narrow weld repair in that the crack is located a short distance from the weld repair fusion line.

Due to a lack of significant driving forces, either hydrostatic or residual stresses, the crack currently does not impact either the structural stability or the leak tightness of the tank. This statement is confirmed by the finite element fracture analysis previously performed on the crack (assuming that it was 15 inches) [21]. The analysis showed that the hydrostatic stresses were not sufficient to drive the crack to instability. The horizontal orientation of the crack means that hydrostatic stresses in the hoop direction will not have a significant impact on further crack growth. Therefore, from a structural stability perspective the crack is not anticipated to be significant during waste removal. If the waste is raised above this level, leakage may occur. Procedures to handle the leakage are in place. 


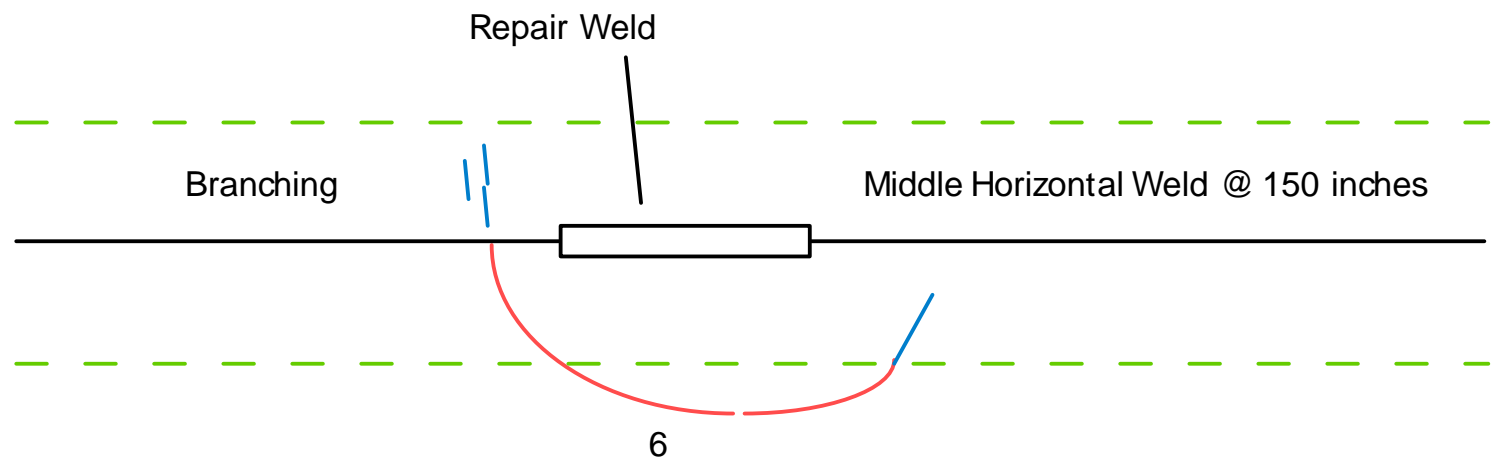

$$
\begin{array}{ll}
- & \text { Weld } \\
- & \text { Through Wall Crack } \\
& \begin{array}{l}
\text { Partial Through Wall } \\
\text { Crack }
\end{array} \\
-\quad-\quad & \begin{array}{l}
\text { Zone } 3 \text { inches from Weld } \\
\text { Center Line }
\end{array}
\end{array}
$$

(a)

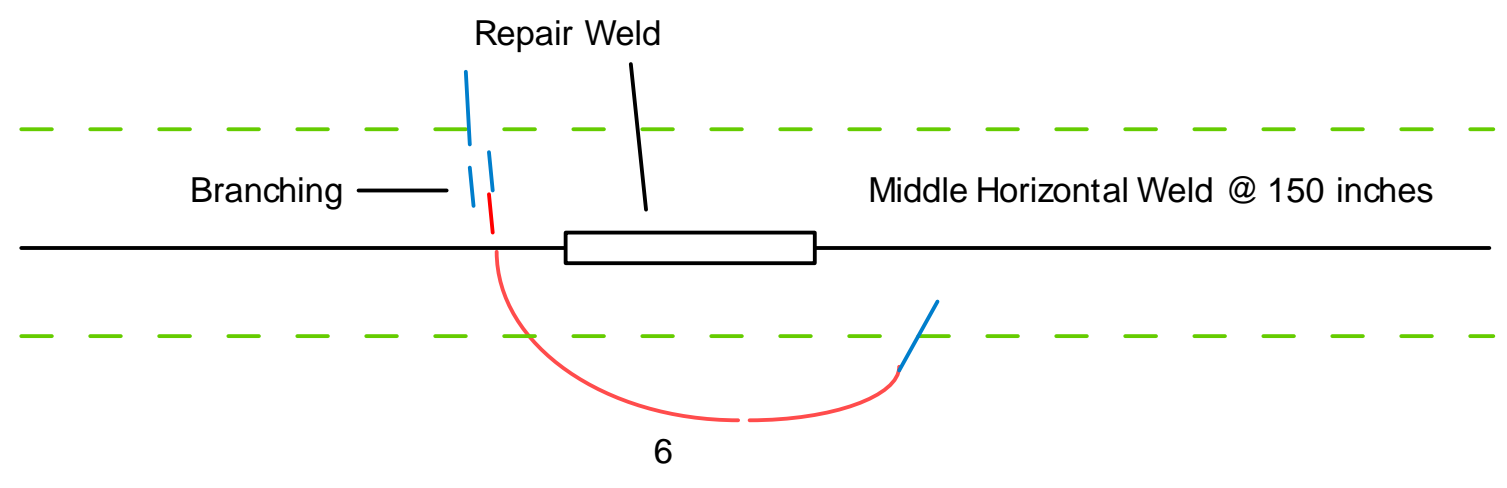

$$
\begin{array}{ll}
- & \text { Weld } \\
- & \text { Through Wall Crack } \\
& \begin{array}{l}
\text { Partial Through Wall } \\
\text { Crack } \\
-\quad-\quad
\end{array} \quad \begin{array}{l}
\text { Zone } 3 \text { inches from Weld } \\
\text { Center Line }
\end{array}
\end{array}
$$

(b)

Figure 24. Rudimentary drawing showing crack \# 6 (a) 2002 and (b) 2007. 

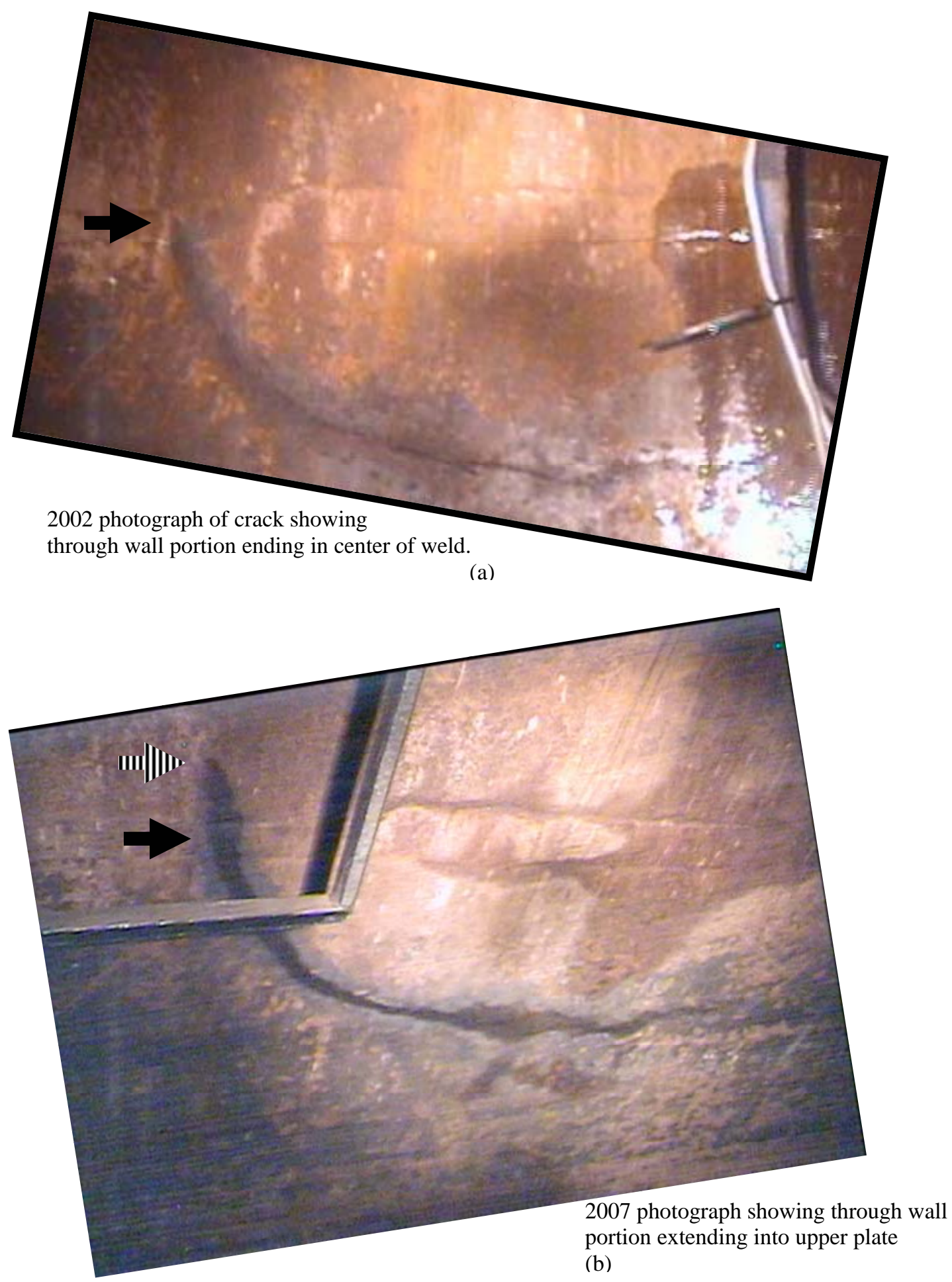

Figure 25. Bleedout photographs of crack \# 6 (a) 2002 and (b) 2007. 


\subsection{Crack \#7}

The rudimentary drawing of crack \#7 is shown in Figure 26. The crack is part through-wall and thus was only detected via the ultrasonic inspection. During the first 21 years of service the crack was exposed to supernate, while for the past 25 years it has been in the vapor space. Because there has been no visual indications of salt leakage, it cannot be determined whether this crack initiated due to supernate or vapor exposure.

The indication is horizontal and located at a vertical weld in the lower shell plate of the tank. The indication is less than $25 \%$ through-wall and is approximately 1.2 inches long. In 2002, it was included with the other cracks because there was sufficient evidence to warrant a further examination. In 2007, it was determined that this indication was not a crack. Improvements, such as the new probe fixtures, have resulted in better scan resolution led to this determination.

\subsection{Crack \#8}

The rudimentary drawing of crack \#8 is shown in Figure 26. There were no previous indications of this crack prior to the ultrasonic inspection. During the first 21 years of service the crack was exposed to supernate, while for the past 25 years it has been in the vapor space. The level history indicates that between 1982-1983 this site was near the liquid-air interface. Though the exact date is unknown, visual inspection results and the limited amount of leakage appear to indicate that through-wall penetration occurred during the past 25 years of vapor exposure. Initiation of the crack may have occurred during the exposure to supernate.

The crack is horizontal and located at a vertical weld in the lower shell plate of the tank. Measurements taken in 2007 indicate that the crack is through-wall and approximately 6.7 inches long, of which 3.3 inches is to the right of the vertical weld and 3.4 inches to the left. The length on the left hand side of the weld includes approximately 1.8 inches of growth since the 2002 inspections. In 2003, it was recognized that since the portion of the crack to the left hand side was within the 3-inch reference zone around the weld, future crack growth was possible. Thus, evidence of growth is not entirely unexpected. It is noted that nearly all of this growth was partial through-wall. In fact, there is only a small portion of this crack immediately adjacent to the weld that has propagated through-wall. As expected, no crack extension was measured to the right of the vertical weld. The crack lies predominantly within the 3 to 5 inch reference zone on either side of the weld and appears to be consistent in length and orientation with cracks observed on the vertical weld in Tank 16.

Due to a lack of significant driving forces, either hydrostatic or residual stresses, the crack currently does not impact either the structural stability or the leak tightness of the tank. The horizontal orientation of the crack means that hydrostatic stresses in the hoop direction will not have a significant impact on further crack growth as well. Therefore, from a structural stability perspective the crack is not anticipated to be significant. If the waste is raised above this level during waste removal, leakage may occur. Procedures to handle the leakage are in place. 


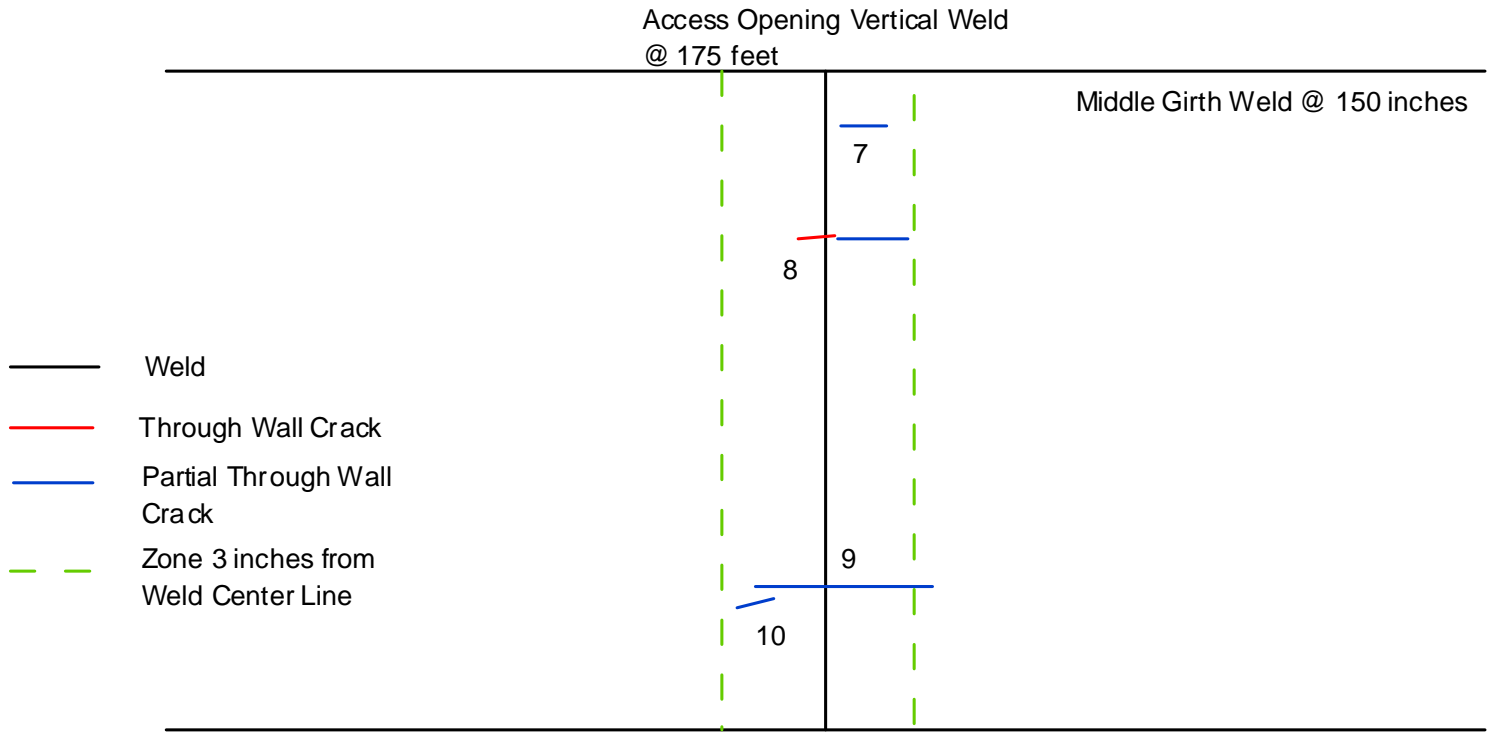

Lower Girth Weld @ 30 inches

(a)

Access Opening Vertical Weld @ 175 feet

Previously suspected crack determined not to be a crack

$\begin{array}{ll}- & \text { Weld } \\ - & \text { Through Wall Crack } \\ -\quad \text { Partial Through Wall } \\ & \text { Crack } \\ -\quad-\quad & \text { Zone } 3 \text { inches from } \\ & \text { Weld Center Line }\end{array}$

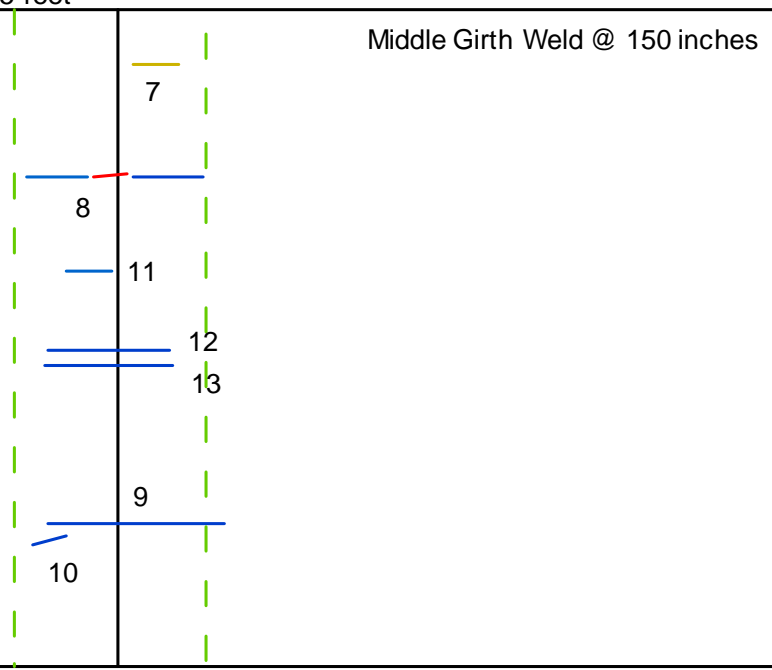

Lower Girth Weld @ 30 inches

(b)

Figure 26. Rudimentary drawing of cracks \#7-13 (a) 2002 and (b) 2007. 


\subsection{Crack \#9}

The rudimentary drawing of crack \#9 is shown in Figure 26. There were no previous indications of this crack prior to the ultrasonic inspection. From 1961-1966 the crack was exposed to supernate. Since that time the crack was covered with sludge. Though the exact date is unknown, the level data indicates that the crack initiated and grew during exposure to supernate or sludge.

The crack is horizontal and located at a vertical weld in the lower shell plate of the tank. The 2007 inspection indicated that the crack is approximately $60 \%$ through-wall and 5 inches long, of which 3 inches is to the right of the vertical weld and 2 inches to the left. No crack growth was detected. The crack lies predominantly within the 3-inch reference zone and appears to be consistent in length and orientation with cracks observed on the vertical weld in Tank 16 . The length of this crack is actually shorter than that reported in 2002. This change may be due to the mechanical improvements to the probe fixtures.

Due to a lack of significant driving forces, either hydrostatic or residual stresses, the crack currently does not impact either the structural stability or the leak tightness of the tank. Since the portion of the crack to the left hand side is within the 3-inch reference zone around the weld, future crack growth is possible. However, maintaining the waste within the corrosion control limits during any future waste removal operations would minimize this possibility. Significant crack extension of the right side branch of the crack due to residual stress is not anticipated. The horizontal orientation of the crack means that hydrostatic stresses in the hoop direction will not have a significant impact on further crack growth. Therefore, from a structural stability perspective the crack is not anticipated to be significant.

\subsection{Crack \#10}

The rudimentary drawing of crack \#10 is shown in Figure 26. From 1961-1966 the crack was exposed to supernate. Since that time the crack was covered with sludge. Though the exact date is unknown, the level data indicates that the crack initiated and grew during exposure to supernate or sludge.

There were no previous indications of this crack prior to the 2002 ultrasonic inspection. The crack is horizontal and located to the left of a vertical weld in the lower shell plate of the tank. Measurements made in 2007 indicate that the crack is approximately $60 \%$ through-wall and 1.5 inches long, and potentially an extension of crack \#9. No crack growth was detected. The total length of the combined crack would then be approximately 6.4 inches. The crack lies predominantly within the 3 -inch reference zone and appears to be consistent in length and orientation with cracks observed on the vertical weld in Tank 16.

Due to a lack of significant driving forces, either hydrostatic or residual stresses, the crack currently does not impact either the structural stability or the leak tightness of the tank. Since the crack is within the 3 to 5 -inch reference zone around the weld, future crack growth is possible. However, maintaining the waste within the corrosion control limits during any future waste removal operations would minimize this possibility. The horizontal orientation of the crack means that hydrostatic stresses in the hoop direction will not have a significant impact on further crack growth. Therefore, from a structural stability perspective the crack is not anticipated to be significant.

\subsection{Crack \#11}

The rudimentary drawing of crack \#11 is shown in Figure 26. During the first 21 years of service the crack was exposed to supernate, while for the past 25 years it has been in the vapor space. Though the exact date is unknown, visual inspection results and the limited amount of leakage appear to indicate that through-wall penetration occurred during the past 25 years of vapor exposure. Initiation of the crack may have occurred during the exposure to supernate.

There were no previous indications of this crack prior to the 2007 ultrasonic inspection. In fact, this area was examined for the first time in 2007. The crack is horizontal to the bottom plate vertical weld and was approximately 25\% through-wall and 1.2 inches long. Due to a lack of significant driving forces, either hydrostatic or residual stresses, and the fact that the crack is part through-wall the crack currently does not 
impact either the structural stability or the leak tightness of the tank. Since the crack is within the 3-inch reference zone around the weld, future crack growth is possible. However, maintaining the waste within the corrosion control limits during any future waste removal operations would minimize this possibility. The horizontal orientation of the crack means that hydrostatic stresses in the hoop direction will not have a significant impact on further crack growth. Therefore, from a structural stability perspective the crack is not anticipated to be significant.

\subsection{Crack \#12}

The rudimentary drawing of crack \#12 is shown in Figure 26. During the first 21 years of service the crack was exposed to supernate, while for the past 25 years it has been in the vapor space. Though the exact date is unknown, visual inspection results and the limited amount of leakage appear to indicate that through-wall penetration occurred during the past 25 years of vapor exposure. Initiation of the crack may have occurred during the exposure to supernate.

There were no previous indications of this crack prior to the 2007 ultrasonic inspection. In fact, this area was examined for the first time in 2007. The crack is horizontal to the bottom plate vertical weld and was approximately 30\% through-wall and 5 inches long. Due to a lack of significant driving forces, either hydrostatic or residual stresses, and the fact that the crack is part through-wall, the crack currently does not impact either the structural stability or the leak tightness of the tank. Since the crack is within the 3-inch reference zone around the weld, future crack growth is possible. However, maintaining the waste within the corrosion control limits during any future waste removal operations would minimize this possibility. The horizontal orientation of the crack means that hydrostatic stresses in the hoop direction will not have a significant impact on further crack growth. Therefore, from a structural stability perspective the crack is not anticipated to be significant.

\subsection{Crack \#13}

The rudimentary drawing of crack \#13 is shown in Figure 26. During the first 21 years of service the crack was exposed to supernate, while for the past 25 years it has been in the vapor space. Though the exact date is unknown, visual inspection results and the limited amount of leakage appear to indicate that through-wall penetration occurred during the past 25 years of vapor exposure. Initiation of the crack may have occurred during the exposure to supernate.

There were no previous indications of this crack prior to the 2007 ultrasonic inspection. In fact, this area was examined for the first time in 2007. The crack is horizontal to the bottom plate vertical weld and was approximately $40 \%$ through-wall and 5 inches long. Due to a lack of significant driving forces, either hydrostatic or residual stresses, and the fact that the crack is part through-wall, the crack currently does not impact either the structural stability or the leak tightness of the tank. Since the crack is within the 3-inch reference zone around the weld, future crack growth is possible. However, maintaining the waste within the corrosion control limits during any future waste removal operations would minimize this possibility. The horizontal orientation of the crack means that hydrostatic stresses in the hoop direction will not have a significant impact on further crack growth. Therefore, from a structural stability perspective the crack is not anticipated to be significant.

\subsection{Crack Growth Rates}

The crack growth rates were estimated based on the change in length between the 2002 and the 2007 measurements divided by the time between the measurements. The results of this calculation are shown in Table 4 for each of the growing cracks. The first observation is that the crack growth rates are approximately 1 to 2 orders of magnitude lower than the crack growth rate observed in a $5 \mathrm{M}$ nitrate solution on a laboratory sample at approximately the same temperature as the Tank 15 wall [24]. The second observation is that the crack growth rate appears to decrease as the distance from the edge of the weld increases. For example, for Crack \#1 in 2002 the distance from the weld was 3.76 inches, whereas for Crack \#10 the distance was 2.2 inches (Note: These are not the total crack length, but the length on one side of the weld). The growth rate for Crack \#10 appears to be approximately 4 times greater than Crack \#1. 
Both of these observations suggest that the stress intensity at the crack tip is decreasing and approaching $\mathrm{K}_{\text {Iscc }}$ as the crack tip approaches the edge of the residual stress zone. The observation that the cracks are only part through-wall at the end also suggests that the cracks are nearing the edge of the residual stress zone.

Table 4. Estimated Crack Growth Rates

\begin{tabular}{|c|c|c|c|c|c|}
\hline & & $\begin{array}{l}\text { Change in } \\
\text { crack } \\
\text { length } \\
\text { (inches) }\end{array}$ & $\begin{array}{l}\text { Crack Growth } \\
\text { Rate } \\
\text { (inches/yr) }\end{array}$ & $\begin{array}{l}\text { Total length of } \\
\text { crack from } \\
\text { edge of the } \\
\text { weld in 2002 } \\
\text { (inches) }\end{array}$ & $\begin{array}{l}\text { Total Length of } \\
\text { crack from edge } \\
\text { of the weld in } \\
\text { 2007 (inches) }\end{array}$ \\
\hline 1 & 1719 & 0.46 & 0.098 & 3.76 & 4.22 \\
\hline 4 & 1693 & 0.25 & 0.054 & 3.84 & 4.1 \\
\hline 6 & 1693 & 1.7 & 0.367 & 2.2 & 3.9 \\
\hline 8 & 1724 & 1.8 & 0.381 & 1.5 & 3.2 \\
\hline $\begin{array}{c}5 \text { M Nitrate } \\
\text { solution at } 50 \\
{ }^{\circ} \mathrm{C}\end{array}$ & & & & & \\
\hline
\end{tabular}

\subsection{Crack Specific Evaluations}

Crack specific evaluations were performed to determine the possibility of unstable crack growth [25]. The Fitness-For Service fracture methodology outlined in API-579 was used for this evaluation [26]. This methodology was also utilized to compute fill limits for Type I and II tanks with cracks [27]. The analysis provided a critical crack length for a given stress level. If the measured crack length is less than the critical crack length, the flaw will continue to propagate at a sub-critical rate. On the other hand, if the measured crack length is greater than the critical crack length uncontrolled, rapid crack growth would occur. The stresses anticipated for waste removal conditions in Tank 15 were utilized. These conditions would certainly bound the current stresses in the tank (i.e., no hydrostatic loads). Crack lengths and locations from the UT inspection were utilized in the analysis.

The stresses considered in the analysis were [24]: hydrostatic, residual, dead load, seismic and loads due to the operation of the submersible mixer pump (SMP). The primary stresses, particularly outside the residual stress zone, will be hydrostatic. The fill level and specific gravity of the waste determine the hydrostatic stress. For the current conditions the hydrostatic stresses are minimal since only small volume of dry sludge remains in Tank 15.

However, for waste removal inhibited water ( $0.01 \mathrm{M}$ sodium hydroxide and $0.011 \mathrm{M}$ sodium nitrite) is added to slurry the sludge for transfer. The specific gravity (SpG) of a sludge slurry is dependent on the soluble salt and insoluble solids concentration of the sludge. Tank 15 sludge has been washed previously and therefore the soluble salt concentration is expected to be relatively low compared to a tank with unwashed sludge, and thus the SpG would be controlled by the inhibited water and the insoluble solids concentration. The last sludge slurry operation produced a sludge slurry with a soluble salt concentration of approximately 5 to $7 \mathrm{wt} . \%$ and a $14 \mathrm{wt} . \%$ insoluble solid concentration (Note: The DSA limit for insoluble solid concentration in a sludge slurry is $16.7 \mathrm{wt} . \%)$. The resulting SpG of this slurry was 1.16 [28]. For the analysis a bounding value of 1.2 was assumed for the SpG of the slurry.

The amount of inhibited water that may be added to a tank during sludge slurry operations is also limited by flammability concerns. This limit is dependent on several factors such as the heat load, soluble salt (i.e., nitrate and nitrite) concentration and interstitial liquid fraction. Tank 15 sludge is high heat, has a low interstitial liquid fraction, and a relatively low soluble salt concentration. The effect of these variables would be to lower the flammability fill level significantly below any structural integrity fill level. WCTables [29], a High Level Waste Division waste characterization database, was utilized to calculate a flammability fill level of 200 inches for Tank 15 (Note: This is not necessarily the final flammability fill 
level that will be utilized for Tank 15. However, the methodology for determining the fill level [30] is the same and therefore is likely a reasonable estimate.).

Each of the cracks that exhibited growth was evaluated against the critical crack length at that location and at the specific orientation of the crack (i.e., either horizontal or vertical) [30]. It was assumed in the analysis that the cracks were completely through-wall. For a horizontal crack, the worst case was the crack that measured 6.7 inches at the 128" elevation. The critical flaw size at this elevation and in this orientation was $>200$ inches, which means that a margin of greater than 30 exists on the measured crack length. For the worst case vertical cracks that exhibited growth (all at elevations greater than 128”), the critical crack length was greater than 50 inches. The longest vertical crack was measured at 10.5 inches, which means that a margin of greater than 5 exists on the measured crack length.

Since the cracks exhibited sub-critical growth, the growth rate for each crack was utilized to estimate the time to reach the critical crack length. For the calculations it was assumed that the growth rate is constant, even at distances that are clearly outside the area affected by the residual stresses from the weld. For the worst case horizontal crack, the growth rate was 0.38 inches/yr. The crack exhibited growth on one side, therefore only extension on one side of the crack will be considered. Given a critical crack length of 200 inches and a current crack length of 6.7 inches the crack will grow to the critical flaw size in approximately 500 years. Likewise, the growth rate for the worst case vertical crack was only 0.05 inches. The crack exhibited growth on one side, therefore only extension on one side of the crack will be considered. Given a critical crack length of 50 inches and a current crack length of 10.5 inches the crack will grow to the critical crack length in approximately 800 years. Therefore, these particular cracks do not represent a threat to the structural stability of Tank 15.

A "worst" case situation was considered to bound conditions in this tank and other Type I and II tanks where cracks exist. A vertical crack 10.5 inches long was located at the 30 inch elevation (i.e., the highest stress area) and it was assumed to grow at a rate of 0.38 inches per year. These assumptions are extremely conservative since only cracks in the vapor space have been observed to grow and in most cases the 30 inch level in Type I and II tanks are covered with salt or sludge (Note: Although there are cracks beneath the salt and sludge in these tanks, no leakage from these cracks is observed.). The critical crack length under these conditions was 24 inches. The time to critical crack length in this instance is approximately 36 years. Although the time to the critical crack length is shorter in this case, there should be plenty of time to either respond by re-inspecting the cracks or to complete waste removal in the tank.

\subsection{Recommendations for the Future Service Life of Tank 15}

In addition to Tank 15, there are three other tanks that have exhibited crack growth in the vapor space: Tanks 5 and 6 in F-Area and Tank 12 in H-area. However, given that the cracks in these tanks, as well as those in Tank 15, appear to remain confined to the residual stress zone around the weld, Tank 15 may continue to be considered as the bounding case for the Type I and II tanks. UT examination of Tank 15 is scheduled for 2014 per the waste tank in-service inspection program [1]. Given the known crack growth rates for Tank 15, crack instability before the re-inspection should not be a concern. It should be noted that the in-service inspection program will be re-evaluated on a three year periodicity. Therefore, changes to the mission for Tank 15 and other Type I and II tanks may be considered by the In-Service Inspection Review Committee and the program adjusted accordingly.

The following recommendations are made for the future service life of Tank 15.

1) Future additions to the tank should be limited to the water necessary to perform sludge slurry operations for waste removal. Once the final flammability fill level is calculated the stability of the cracks should be re-evaluated to verify the calculations performed. Although it is not anticipated that the addition of water will result in crack extension, leakage of the waste should be minimized. Procedures exist for handling leakage of waste into the annulus.

2) Prior to grouting for final closure of Tank 15, re-inspection and measurement of the cracks may be necessary since the tank wall is considered to be a barrier to the residual radionuclides. 


\subsection{References}

1. B. J. Wiersma, K. H. Subramanian., et.al., "In-Service Inspection Program for High Level Waste Tanks,” WSRC-TR-2002-00061, Rev. 2, June 2003.

2. J. B. Elder, "SRS Type II HLW Tank 15 NDE Inspection Results", WSRC-TR-2002-00565, February 24, 2003.

3. J. B. Elder, “Tank Inspection NDE Results for Fiscal Year 2007 Including Waste Tanks 35, 36, 37, 38, and Tank 15”, WSRC-TR-2007-00064, September 27, 2007.

4. R. L. Sindelar and B. J. Wiersma, "SRS High Level Waste Tank and Piping Systems - Structural Integrity Program and Topical Report”, WSRC-TR-95-0076, June 1995.

5. B. J. Wiersma and P. E. Zapp, "Structural Dimensions, Fabrication, Materials and Operational History for Types I and II Waste Tanks”, WSRC-TR-98-00373, October 1998.

6. B. J. Wiersma and R. L. Sindelar, "Reference Flaw Size for Structural and Fracture Analysis of Types I and II Waste Tanks”, WSRC-TR-94-041, January 1994.

7. "Standard Specification for Low and Intermediate Tensile Strength Carbon Steel Plates of Flange and Firebox Qualities”, ASTM A285-50 T, Issued May 1949, Revised, December 1949, September and December 1950.

8. T. L. Davis, et. al., "History of Waste Tank 16: 1959 through 1974”, DPSPU-77-11-17, July 1977.

9. Waste Management Monthly Data Record, December 1988, MO-RPT-88-DEC1, January 24, 1989

10. L. A. Strong, "Assessment of Environmental Conditions in the Tank 15 Vapor Space”, WSRC-TR-9900412, December 1999.

11. "Investigation of Waste Tank Leakage Savannah River Plant”, DPE-2207, April 1962.

12. W. L. Poe, "Leakage from Waste Tank 16: Amount, Fate and Impact”, DP-1358, November 1974.

13. R. M. Girdler, "Leaks in Radioactive Waste Tanks”, DP-990, December 1965.

14. R. F. Mittelberg, “Outside Surface Waste Tank No. 16”, 200-H Area Metallurgical Report, June 3, 1974.

15. L. P. Costas, M. L. Holzworth, and W. C. Rion, "Stress Corrosion Cracking of Carbon Steel in Simulated Waste Solutions”, DP-1023, June 1966.

16. P. Dong, J. Zhang, J. K. Hong, and F. W. Brust, “Task 1: Residual Stresses and Stress Intensity Factors for Single Butt Welds”, Battelle Center for Welded Structures Research, Report No. G003824-01, September 1999.

17. P. Dong, J. Zhang, J. K. Hong, and F. W. Brust, “Task 2: Residual Stresses and Stress Intensity Factors for Intersecting Horizontal and Vertical Seam Welds”, Battelle Center for Welded Structures Research, Report No. G003824-02, November 1999.

18. P. Dong, J. Zhang, J. K. Hong, and F. W. Brust, “Task 3: Residual Stresses and Stress Intensity Factors for Weld Repairs and Attachments”, Battelle Center for Welded Structures Research, Report No. G0038240-03, February 2000.

19. J. A. Donovan, "Materials Aspects of SRP Waste Storage - Corrosion and Mechanical Failures", DP1476, November 1977.

20. P. E. Zapp and P-S. Lam, "Preliminary Evaluation of Tank 15 Vapor Space Cracking”, WSRC-TR2000-00187, June 2000.

21. B. J. Wiersma, “A Structural Impact Assessment of Flaws Detected During Ultrasonic Examination of Tank 15”, WSRC-TR-2002-00590, March 2003.

22. P-S. Lam, "Estimation of Instability Flaw Lengths for Tank 6", WSRC-TR-2001-00172, March 2001.

23. F. G. McNatt, “Annual Radioactive Waste Tank Inspection Program - 1994”, WSRC-TR-95-166, May 1995.

24. J. A. Donovan, "Resistance of Type A-537 Class I Steel to Nitrate Stress Corrosion Cracking”, DPST81-687, September, 1981.

25. C. A. McKeel, "Calculation of Critical Crack Lengths in HLW Tank 15", T-CLC-H-00890, June 2008.

26. Recommended Practice for Fitness-for-Service, API-579, American Petroleum Institute, January 2000.

27. R. R. Rothermel, "Fracture Evaluation Methodology for High Level Waste Tanks”, T-CLC-G-00137, December 1999.

28. B. A. Hamm, "High Level Caves Rheological Studies of Tank 15H, 42H, and 8F Sludge/Slurries", DPST-84-439, April 1984.

29. WCTables Waste Characterization Database. 
30. G. J. Hutchens, “Formulae for Flammability Control”, HLW-CSTE-98-0049, Rev. 2, March 1999. 


\section{Appendix 1}

Table A1. Detailed Crack Descriptions

\begin{tabular}{|c|c|c|c|c|c|c|c|}
\hline $\begin{array}{l}\text { Crack } \\
\text { ID }\end{array}$ & $\begin{array}{l}\text { UT Inspection Report } \\
\text { Number }\end{array}$ & $\begin{array}{l}\text { Previously } \\
\text { Identified? }\end{array}$ & $\begin{array}{l}\text { Service } \\
\text { Environment }\end{array}$ & Location & Orientation & Length & Additional Comments \\
\hline 1 & $\begin{array}{l}\text { 2002-IR-06-UT-0677 \& } \\
\text { 2007-IR-11-0648 }\end{array}$ & $\begin{array}{l}\text { Crack was } \\
\text { identified in } \\
\text { 1998. At this } \\
\text { time the waste } \\
\text { level was well } \\
\text { below the crack. } \\
\text { No leakage was } \\
\text { associated with } \\
\text { the crack. }\end{array}$ & $\begin{array}{l}\text { 1961-82 Supernate } \\
\text { 1982-Present } \\
\text { Vapor Space }\end{array}$ & $\begin{array}{l}\text { Vertical weld at } 53 \\
\text { feet clockwise from } \\
\text { the south riser and } \\
200 \text { inches above } \\
\text { the tank bottom. }\end{array}$ & $\begin{array}{l}\text { The crack is } \\
\text { perpendicular to } \\
\text { the weld. }\end{array}$ & $\begin{array}{l}\text { In 2002, the } \\
\text { through wall } \\
\text { portion of the crack } \\
\text { was approximately } \\
1.4 \text { inches. The } \\
\text { crack extends out } \\
\text { to approximately } \\
3.7 \text { inches part } \\
\text { through wall. } \\
\text { In } 2007 \text {, the portion } \\
\text { of the crack to the } \\
\text { right of the vertical } \\
\text { weld exhibited } \\
0.46 \text { " of growth. } \\
\text { The portion of the } \\
\text { crack to the left of } \\
\text { the vertical weld } \\
\text { was also measured. } \\
\text { The total crack } \\
\text { length was } 9.54 \text { ". }\end{array}$ & $\begin{array}{l}\text { In 2002, UT was performed } \\
\text { only on the portion of the } \\
\text { crack to the right of the } \\
\text { vertical weld. Visuals } \\
\text { indicated that the crack } \\
\text { extends through the weld to } \\
\text { the other side. No other } \\
\text { areas on the vertical weld } \\
\text { were scanned. } \\
\text { In 2007, improvements to } \\
\text { the probe holder fixture } \\
\text { allowed more accurate } \\
\text { sizing of the crack. }\end{array}$ \\
\hline 2 & $\begin{array}{l}\text { 2002-IR-06-UT-0746 \& } \\
\text { 2007-IR-11-0647 }\end{array}$ & $\begin{array}{l}\text { Leak site was } \\
\text { identified in } \\
\text { 1973. A salt } \\
\text { deposit was } \\
\text { associated with } \\
\text { the crack. }\end{array}$ & $\begin{array}{l}\text { 1961-1968 } \\
\text { Supernate } \\
\text { 1968-1982 } \\
\text { Sludge (at times } \\
\text { near sludge liquid } \\
\text { interface) } \\
\text { 1982-1989 } \\
\text { Supernate } \\
\text { 1989-Present } \\
\text { Vapor Space }\end{array}$ & $\begin{array}{l}\text { Mid-plate at } 115 \\
\text { feet clockwise from } \\
\text { the south riser and } \\
88 \text { inches above the } \\
\text { tank bottom. }\end{array}$ & $\begin{array}{l}\text { The crack is arc } \\
\text { shaped. }\end{array}$ & $\begin{array}{l}\text { In } 2002 \text { the crack } \\
\text { was } 100 \% \text { through- } \\
\text { wall. The portion } \\
\text { of the arc measured } \\
\text { by UT was } \\
\text { approximately } 3.7 \\
\text { inches in the } \\
\text { vertical direction } \\
\text { and } 2.3 \text { inches in } \\
\text { the horizontal. No } \\
\text { measurable growth } \\
\text { was determined in } \\
2007\end{array}$ & $\begin{array}{l}\text { An attachment on the } \\
\text { exterior of the tank exists. } \\
\text { The exact length could not } \\
\text { be determined due to this } \\
\text { obstruction. When the area } \\
\text { was wetted, "bleed } \\
\text { through" was observed } \\
\text { providing further evidence } \\
\text { that the crack continued } \\
\text { through the obstruction } \\
\text { area. }\end{array}$ \\
\hline
\end{tabular}


Table A1. (continued)

\begin{tabular}{|c|c|c|c|c|c|c|c|}
\hline $\begin{array}{l}\text { Crack } \\
\text { ID }\end{array}$ & $\begin{array}{l}\text { UT Inspection Report } \\
\text { Number }\end{array}$ & $\begin{array}{l}\text { Previously } \\
\text { Identified? }\end{array}$ & $\begin{array}{l}\text { Service } \\
\text { Environment }\end{array}$ & Location & Orientation & Length & Additional Comments \\
\hline 3 & $\begin{array}{l}\text { 2002-IR-06-UT-0943 \& } \\
\text { 2007-IR-11-0650 }\end{array}$ & $\begin{array}{l}\text { No previous } \\
\text { observations. }\end{array}$ & $\begin{array}{l}\text { 1961-1965 } \\
\text { Supernate } \\
\text { 1965-Present } \\
\text { Sludge }\end{array}$ & $\begin{array}{l}\text { Bottom horizontal } \\
\text { weld at } 181 \text { feet } \\
\text { clockwise from the } \\
\text { south riser and } 30 \\
\text { inches above the } \\
\text { tank bottom. }\end{array}$ & $\begin{array}{l}\text { The crack is } \\
\text { perpendicular to } \\
\text { the weld. }\end{array}$ & $\begin{array}{l}\text { In } 2002, \text { the crack } \\
\text { was approximately } \\
20 \% \text { through wall } \\
\text { and } 0.55 \text { inches } \\
\text { long. No growth } \\
\text { was detected in } \\
2007 .\end{array}$ & $\begin{array}{l}\text { The crack is approximately } \\
0.8 \text { inches above the } \\
\text { horizontal weld. }\end{array}$ \\
\hline $4 a$ & $\begin{array}{l}\text { 2002-IR-06-UT-0938 \& } \\
\text { 2007-IR-11-00651 }\end{array}$ & $\begin{array}{l}\text { Leak site was } \\
\text { identified in } \\
\text { 1973. A salt } \\
\text { deposit was } \\
\text { associated with } \\
\text { the crack. }\end{array}$ & $\begin{array}{l}\text { 1961-1982 } \\
\text { Supernate } \\
\text { 1982-Present } \\
\text { Vapor Space }\end{array}$ & $\begin{array}{l}\text { Near the } \\
\text { intersection of a } \\
\text { vertical and } \\
\text { horizontal weld at } \\
172 \text { feet clockwise } \\
\text { from the south riser } \\
\text { and } 150 \text { inches } \\
\text { above the bottom } \\
\text { of the tank. }\end{array}$ & $\begin{array}{l}\text { The crack is } \\
\text { perpendicular to } \\
\text { and runs across the } \\
\text { horizontal weld. } \\
\text { Below the } \\
\text { horizontal weld, } \\
\text { the crack is parallel } \\
\text { to the vertical weld. }\end{array}$ & $\begin{array}{l}\text { In 2002, The total } \\
\text { length of the crack } \\
\text { was measured at } \\
7.88 \text { inches. The } \\
\text { total through wall } \\
\text { length is } 7 \text { inches. } \\
\text { The partial through } \\
\text { wall portion is at } \\
\text { the ends of the } \\
\text { crack } \\
\text { (approximately 0.4- } \\
0.5 \text { inches). } \\
\text { In } 2007 \text {, it was } \\
\text { clear that } 4 a, 4 b \text {, } \\
\text { and } 4 \mathrm{c} \text { were part of } \\
\text { the same branched } \\
\text { crack network. } \\
\text { The longest branch } \\
\text { of the crack was } \\
\text { 10.5”. It was } \\
\text { estimated that the } \\
\text { crack grew } \\
\text { approximately } 0.25 \\
\text { inches. }\end{array}$ & $\begin{array}{l}\text { The crack is approximately } \\
2 \text { inches to the right of the } \\
\text { vertical weld. Two weld } \\
\text { beads on the interior of the } \\
\text { tank are approximately } 2 \\
\text { inches to the left of the } \\
\text { crack. Cracks } 4 \mathrm{~b} \text { and } 4 \mathrm{c} \\
\text { appear to be connected to } \\
\text { this crack although they are } \\
\text { only part through wall. If } \\
\text { these crack lengths are } \\
\text { added together the total } \\
\text { length would be } \\
\text { approximately } 10.7 \text { inches. }\end{array}$ \\
\hline
\end{tabular}


Table A1. (continued)

\begin{tabular}{|c|c|c|c|c|c|c|c|}
\hline Crack ID & $\begin{array}{l}\text { UT Inspection } \\
\text { Report Number }\end{array}$ & $\begin{array}{l}\text { Previously } \\
\text { Identified? }\end{array}$ & $\begin{array}{l}\text { Service } \\
\text { Environment }\end{array}$ & Location & Orientation & Length & $\begin{array}{l}\text { Additional } \\
\text { Comments }\end{array}$ \\
\hline $4 \mathrm{~b}$ & $\begin{array}{l}\text { 2002-IR-06-UT- } \\
0938 \text { \& 2007-IR- } \\
11-00651\end{array}$ & $\begin{array}{l}\text { Leak site was } \\
\text { identified in } 1973 . \\
\text { Salt deposit due to } \\
\text { through wall } \\
\text { portion of crack 4a. }\end{array}$ & $\begin{array}{l}\text { 1961-1982 } \\
\text { Supernate } \\
\text { 1982-Present } \\
\text { Vapor Space }\end{array}$ & $\begin{array}{l}\text { Near the } \\
\text { intersection of a } \\
\text { vertical and middle } \\
\text { horizontal weld at } \\
172 \text { feet clockwise } \\
\text { from the south riser } \\
\text { and } 150 \text { inches } \\
\text { above the bottom } \\
\text { of the tank. }\end{array}$ & $\begin{array}{l}\text { The crack is } \\
\text { parallel to the } \\
\text { vertical weld. }\end{array}$ & $\begin{array}{l}\text { The crack is } \\
\text { approximately } 50 \% \\
\text { through wall and } 1 \\
\text { inch long. }\end{array}$ & $\begin{array}{l}\text { Crack is } \\
\text { approximately } 1.0 \\
\text { inches to the right } \\
\text { of the vertical } \\
\text { weld. }\end{array}$ \\
\hline $4 c$ & $\begin{array}{l}\text { 2002-IR-06-UT- } \\
0938 \text { \& 2007-IR- } \\
11-00651\end{array}$ & $\begin{array}{l}\text { Leak site was } \\
\text { identified in } 1973 . \\
\text { Salt deposit due to } \\
\text { through wall } \\
\text { portion of crack 4a. }\end{array}$ & $\begin{array}{l}\text { 1961-1982 } \\
\text { Supernate } \\
\text { 1982-Present } \\
\text { Vapor Space }\end{array}$ & $\begin{array}{l}\text { Near the } \\
\text { intersection of a } \\
\text { vertical and middle } \\
\text { horizontal weld at } \\
172 \text { feet clockwise } \\
\text { from the south riser } \\
\text { and } 150 \text { inches } \\
\text { above the bottom } \\
\text { of the tank. }\end{array}$ & $\begin{array}{l}\text { The crack is } \\
\text { parallel to the } \\
\text { vertical weld. }\end{array}$ & $\begin{array}{l}\text { The crack is } \\
\text { approximately } 50 \% \\
\text { through wall and } \\
1.8 \text { inches long. }\end{array}$ & $\begin{array}{l}\text { Crack is } \\
\text { approximately } 1.8 \\
\text { inches to the right } \\
\text { of the vertical } \\
\text { weld. }\end{array}$ \\
\hline 5 & $\begin{array}{l}\text { 2002-IR-06-UT- } \\
0939 \text { \& 2007-IR- } \\
11-0651\end{array}$ & $\begin{array}{l}\text { Crack was } \\
\text { identified in } 1998 . \\
\text { Limited amount of } \\
\text { salt was associated } \\
\text { with the crack. }\end{array}$ & $\begin{array}{l}\text { 1961-1982 } \\
\text { Supernate } \\
\text { 1982-Present } \\
\text { Vapor Space }\end{array}$ & $\begin{array}{l}\text { Middle horizontal } \\
\text { weld at } 192 \text { feet } \\
\text { clockwise from the } \\
\text { south riser and } 150 \\
\text { inches above the } \\
\text { tank bottom. }\end{array}$ & $\begin{array}{l}\text { The crack is arc } \\
\text { shaped around a } \\
\text { horizontal repair } \\
\text { weld. }\end{array}$ & $\begin{array}{l}\text { In 2002, the crack } \\
\text { was approximately } \\
10.2 \text { through wall. } \\
\text { The total length of } \\
\text { the crack is } 18.1 \\
\text { inches. } \\
\text { In 2007, the } \\
\text { measured crack } \\
\text { length was } 20.4 \\
\text { inches. This } \\
\text { increase was not } \\
\text { due to crack } \\
\text { growth, but rather } \\
\text { improved probe } \\
\text { fixture design. }\end{array}$ & $\begin{array}{l}\text { The crack is below } \\
\text { the horizontal } \\
\text { weld. This crack } \\
\text { was on the edge of } \\
\text { the visual field. } \\
\text { Therefore no direct } \\
\text { photography had } \\
\text { been performed on } \\
\text { the crack until the } \\
\text { crawler carried a } \\
\text { camera to the site. }\end{array}$ \\
\hline
\end{tabular}


Table A1. (continued)

\begin{tabular}{|c|c|c|c|c|c|c|c|}
\hline Crack ID & $\begin{array}{l}\text { UT Inspection } \\
\text { Report Number }\end{array}$ & $\begin{array}{l}\text { Previously } \\
\text { Identified? }\end{array}$ & $\begin{array}{l}\text { Service } \\
\text { Environment }\end{array}$ & Location & Orientation & Length & $\begin{array}{l}\text { Additional } \\
\text { Comments }\end{array}$ \\
\hline 6 & $\begin{array}{l}\text { 2002-IR-06-UT- } \\
0941 \text { \& 2007-IR- } \\
11-0651\end{array}$ & $\begin{array}{l}\text { Indication was } \\
\text { initially observed } \\
\text { in 1994. The } \\
\text { indication was } \\
\text { declared a crack in } \\
\text { 1997. No salt } \\
\text { deposit was } \\
\text { associated with the } \\
\text { crack. }\end{array}$ & $\begin{array}{l}\text { 1961-1982 } \\
\text { Supernate } \\
\text { 1982-Present } \\
\text { Vapor Space }\end{array}$ & $\begin{array}{l}\text { Middle horizontal } \\
\text { weld @ } 207 \text { feet } \\
\text { clockwise from the } \\
\text { south riser and } 150 \\
\text { inches above the } \\
\text { tank bottom. }\end{array}$ & $\begin{array}{l}\text { The crack is arc } \\
\text { shaped around a } \\
\text { horizontal repair } \\
\text { weld. }\end{array}$ & $\begin{array}{l}\text { In } 2002 \text {, the portion } \\
\text { of the arc that was } \\
\text { through wall was } \\
\text { approximately } 12.7 \\
\text { inches. The total } \\
\text { length of the crack } \\
\text { is } 17.5 \text { inches. } \\
\text { In } 2007 \text {, the total } \\
\text { crack length was } \\
\text { approximately } 19 \\
\text { inches. } 1.7 \text { inches } \\
\text { of crack growth } \\
\text { into the top plate } \\
\text { had occurred. The } \\
\text { longest vertical } \\
\text { portion of the crack } \\
\text { was } 9.6 \text { inches. }\end{array}$ & $\begin{array}{l}\text { The crack is below } \\
\text { the horizontal } \\
\text { weld. A portion of } \\
\text { the crack on the left } \\
\text { had side extends } \\
\text { above the } \\
\text { horizontal weld. } \\
\text { This portion is } \\
\text { partial through wall } \\
\text { and there is } \\
\text { evidence of } \\
\text { branching. From } \\
\text { the tip of the } \\
\text { branched cracks to } \\
\text { the minimum in the } \\
\text { arc is } \\
\text { approximately } 8 \\
\text { inches. A vertical } \\
\text { weld is nearby to } \\
\text { the right hand tip of } \\
\text { the crack. }\end{array}$ \\
\hline 7 & $\begin{array}{l}\text { 2002-IR-06-UT- } \\
0942 \text { \& 2007-IR- } \\
11-0650\end{array}$ & $\begin{array}{l}\text { No previous } \\
\text { observations. }\end{array}$ & $\begin{array}{l}\text { 1961-1982 } \\
\text { Supernate } \\
\text { 1982-Present } \\
\text { Vapor Space }\end{array}$ & $\begin{array}{l}\text { Access opening } \\
\text { vertical weld @ } \\
175 \text { feet clockwise } \\
\text { from the south riser } \\
\text { and } 139 \text { inches } \\
\text { above the tank } \\
\text { bottom. }\end{array}$ & $\begin{array}{l}\text { The crack is } \\
\text { perpendicular to } \\
\text { the vertical weld. }\end{array}$ & $\begin{array}{l}\text { In } 2002 \text {, the crack } \\
\text { was approximately } \\
25 \% \text { through wall } \\
\text { and } 1.17 \text { inches } \\
\text { long. } \\
\text { In } 2007 \text {,this } \\
\text { indication was } \\
\text { declared to not be a } \\
\text { crack. }\end{array}$ & $\begin{array}{l}\text { The crack is to the } \\
\text { right of the vertical } \\
\text { weld. }\end{array}$ \\
\hline
\end{tabular}


Table A1. (continued)

\begin{tabular}{|c|c|c|c|c|c|c|c|}
\hline Crack ID & $\begin{array}{l}\text { UT Inspection } \\
\text { Report Number }\end{array}$ & $\begin{array}{l}\text { Previously } \\
\text { Identified? }\end{array}$ & $\begin{array}{l}\text { Service } \\
\text { Environment }\end{array}$ & Location & Orientation & Length & $\begin{array}{l}\text { Additional } \\
\text { Comments }\end{array}$ \\
\hline 8 & $\begin{array}{l}\text { 2002-IR-06-UT- } \\
0942 \text { \& 2007-IR- } \\
11-0650\end{array}$ & $\begin{array}{l}\text { No previous } \\
\text { observations. No } \\
\text { salt deposits were } \\
\text { associated with } \\
\text { crack. }\end{array}$ & $\begin{array}{l}\text { 1961-1982 } \\
\text { Supernate } \\
\text { 1982-Present } \\
\text { Vapor Space } \\
\text { (1982-83 location } \\
\text { is near the liquid } \\
\text { air interface) }\end{array}$ & $\begin{array}{l}\text { Access opening } \\
\text { vertical weld @ } \\
175 \text { feet clockwise } \\
\text { from the south riser } \\
\text { and } 129 \text { inches } \\
\text { above the tank } \\
\text { bottom. }\end{array}$ & $\begin{array}{l}\text { The crack is } \\
\text { perpendicular to } \\
\text { the vertical weld. }\end{array}$ & $\begin{array}{l}\text { In 2002, the crack } \\
\text { was through wall } \\
\text { and approximately } \\
4.5 \text { inches. } \\
\text { In } 2007 \text {, the crack } \\
\text { length was } 6.7 \\
\text { inches. It was } \\
\text { determined that } 1.8 \\
\text { inches of growth } \\
\text { had occurred. }\end{array}$ & $\begin{array}{l}\text { The crack crosses } \\
\text { the vertical weld. } \\
\text { Approximately } 3.3 \\
\text { inches of the crack } \\
\text { is to the right of the } \\
\text { vertical weld and } \\
\text { approximately } 1.2 \\
\text { inches of the crack } \\
\text { is to the left. }\end{array}$ \\
\hline 9 & $\begin{array}{l}\text { 2002-IR-06-UT- } \\
0942 \text { \& 2007-IR- } \\
11-0650\end{array}$ & $\begin{array}{l}\text { No previous } \\
\text { observations. }\end{array}$ & $\begin{array}{l}\text { 1961-1966 } \\
\text { Supernate } \\
\text { 1966-Present } \\
\text { Sludge }\end{array}$ & $\begin{array}{l}\text { Access opening } \\
\text { vertical weld @ } \\
175 \text { feet clockwise } \\
\text { from the south riser } \\
\text { and } 50 \text { inches } \\
\text { above the tank } \\
\text { bottom. }\end{array}$ & $\begin{array}{l}\text { The crack is } \\
\text { perpendicular to } \\
\text { the vertical weld. }\end{array}$ & $\begin{array}{l}\text { In 2002, the crack } \\
\text { was approximately } \\
60 \% \text { through wall } \\
\text { and } 5.8 \text { inches } \\
\text { long. } \\
\text { In 2007, the crack } \\
\text { length was } 5 \text { inches } \\
\text { and the depth was } \\
\text { approximately } \\
60 \% \text {. The } \\
\text { difference in length } \\
\text { is attributed to } \\
\text { improvement in the } \\
\text { probe fixture. No } \\
\text { growth was } \\
\text { detected. }\end{array}$ & $\begin{array}{l}\text { The crack crosses } \\
\text { the vertical weld. } \\
\text { Approximately } 3.5 \\
\text { inches of the crack } \\
\text { is to the right of the } \\
\text { vertical weld and } \\
\text { approximately } 2.3 \\
\text { inches of the crack } \\
\text { is to the left. }\end{array}$ \\
\hline
\end{tabular}


Table A1. (continued)

\begin{tabular}{|c|c|c|c|c|c|c|c|}
\hline Crack ID & $\begin{array}{l}\text { UT Inspection } \\
\text { Report Number }\end{array}$ & $\begin{array}{l}\text { Previously } \\
\text { Identified? }\end{array}$ & $\begin{array}{l}\text { Service } \\
\text { Environment }\end{array}$ & Location & Orientation & Length & $\begin{array}{l}\text { Additional } \\
\text { Comments }\end{array}$ \\
\hline 10 & $\begin{array}{l}\text { 2002-IR-06-UT- } \\
0942 \text { \& 2007-IR- } \\
11-0650\end{array}$ & $\begin{array}{l}\text { No previous } \\
\text { observations. }\end{array}$ & $\begin{array}{l}\text { 1961-1966 } \\
\text { Supernate } \\
\text { 1966-Present } \\
\text { Sludge }\end{array}$ & $\begin{array}{l}\text { Access opening } \\
\text { vertical weld @ } \\
175 \text { feet clockwise } \\
\text { from the south riser } \\
\text { and } 49 \text { inches } \\
\text { above the tank } \\
\text { bottom. }\end{array}$ & $\begin{array}{l}\text { The crack is at a } \\
\text { slight angle to the } \\
\text { vertical weld. }\end{array}$ & $\begin{array}{l}\text { In 2002, the crack } \\
\text { ws approximately } \\
60 \% \text { through wall } \\
\text { and } 1.4 \text { inches } \\
\text { long. } \\
\text { In 2007, the crack } \\
\text { ws approximately } \\
60 \% \text { through wall } \\
\text { and } 1.5 \text { inches } \\
\text { long. The } \\
\text { difference in length } \\
\text { is attributed to } \\
\text { improvement in the } \\
\text { probe fixture. No } \\
\text { growth was } \\
\text { detected. }\end{array}$ & $\begin{array}{l}\text { The crack is to the } \\
\text { left of the vertical } \\
\text { weld and appears } \\
\text { to be a branch off } \\
\text { of } 9 \text { a. If the cracks } \\
\text { were combined, the } \\
\text { length would be } \\
\text { approximately } 6.4 \\
\text { inches. The angle } \\
\text { of the crack is not } \\
\text { far from } \\
\text { perpendicular to } \\
\text { the vertical weld. }\end{array}$ \\
\hline 11 & 2007-IR-11-0650 & $\begin{array}{l}\text { No previous } \\
\text { observations }\end{array}$ & $\begin{array}{l}\text { 1961-1982 } \\
\text { Supernate } \\
\text { 1982-Present } \\
\text { Vapor Space } \\
\text { (1982-83 location } \\
\text { is near the liquid } \\
\text { air interface) }\end{array}$ & $\begin{array}{l}\text { Access opening } \\
\text { vertical weld @ } \\
175 \text { feet clockwise } \\
\text { from the south riser } \\
\text { and } 104 \text { inches } \\
\text { above the tank } \\
\text { bottom. }\end{array}$ & $\begin{array}{l}\text { The crack is } \\
\text { perpendicular to } \\
\text { the vertical weld. }\end{array}$ & $\begin{array}{l}\text { In } 2007 \text {, the crack } \\
\text { was } 1.2 \text { inches long } \\
\text { and approximately } \\
25 \% \text { through-wall. }\end{array}$ & $\begin{array}{l}\text { Crack was not } \\
\text { detected in 2002, } \\
\text { because the area } \\
\text { was not scanned. }\end{array}$ \\
\hline 12 & 2007-IR-11-0650 & $\begin{array}{l}\text { No previous } \\
\text { observations }\end{array}$ & $\begin{array}{l}\text { 1961-1982 } \\
\text { Supernate } \\
\text { 1982-Present } \\
\text { Vapor Space } \\
\text { (1982-83 location } \\
\text { is near the liquid } \\
\text { air interface) }\end{array}$ & $\begin{array}{l}\text { Access opening } \\
\text { vertical weld @ } \\
175 \text { feet clockwise } \\
\text { from the south riser } \\
\text { and } 72 \text { inches } \\
\text { above the tank } \\
\text { bottom. }\end{array}$ & $\begin{array}{l}\text { The crack is } \\
\text { perpendicular to } \\
\text { the vertical weld. }\end{array}$ & $\begin{array}{l}\text { In } 2007 \text {, the crack } \\
\text { was } 5 \text { inches long } \\
\text { and approximately } \\
30 \% \text { through-wall. }\end{array}$ & $\begin{array}{l}\text { Crack was not } \\
\text { detected in 2002, } \\
\text { because the area } \\
\text { was not scanned. }\end{array}$ \\
\hline
\end{tabular}


Table A1. (continued)

\begin{tabular}{|c|c|c|c|c|c|c|c|}
\hline Crack ID & $\begin{array}{l}\text { UT Inspection } \\
\text { Report Number }\end{array}$ & $\begin{array}{l}\text { Previously } \\
\text { Identified? }\end{array}$ & $\begin{array}{l}\text { Service } \\
\text { Environment }\end{array}$ & Location & Orientation & Length & $\begin{array}{l}\text { Additional } \\
\text { Comments }\end{array}$ \\
\hline 13 & 2007-IR-11-0650 & $\begin{array}{l}\text { No previous } \\
\text { observations }\end{array}$ & $\begin{array}{l}\text { 1961-1982 } \\
\text { Supernate } \\
\text { 1982-Present } \\
\text { Vapor Space } \\
\text { (1982-83 location } \\
\text { is near the liquid } \\
\text { air interface) }\end{array}$ & $\begin{array}{l}\text { Access opening } \\
\text { vertical weld @ } \\
175 \text { feet clockwise } \\
\text { from the south riser } \\
\text { and } 70 \text { inches } \\
\text { above the tank } \\
\text { bottom. }\end{array}$ & $\begin{array}{l}\text { The crack is } \\
\text { perpendicular to } \\
\text { the vertical weld. }\end{array}$ & $\begin{array}{l}\text { In } 2007 \text {, the crack } \\
\text { was } 5.4 \text { inches long } \\
\text { and approximately } \\
40 \% \text { through-wall. }\end{array}$ & $\begin{array}{l}\text { Crack was not } \\
\text { detected in 2002, } \\
\text { because the area } \\
\text { was not scanned. }\end{array}$ \\
\hline
\end{tabular}

Table A2. Coordination between Crack Identification Numbers in SRNS-STI-2008-00028 and WSRC-TR-2007-00064 (See Table 8)

\begin{tabular}{|c|c|}
\hline $\begin{array}{c}\text { Crack Identification Number } \\
\text { SRNS-STI-2008-00028 }\end{array}$ & WSRC-TR-2007-00064 \\
\hline 1 & 1 \\
\hline 2 & 2 \\
\hline 3 & 8 \\
\hline 4 & 3 \\
\hline 5 & 9 \\
\hline 6 & 10 \\
\hline 7 & 4 \\
\hline 8 & 5 \\
\hline 9 & 6 \\
\hline 10 & 7 \\
\hline 11 & $\begin{array}{c}175 \text { ft from south riser, } 104 \\
\text { inches from tank bottom }\end{array}$ \\
\hline 12 & $\begin{array}{c}175 \text { ft from south riser, } 72 \text { inches } \\
\text { from tank bottom }\end{array}$ \\
\hline 13 & $\begin{array}{c}175 \text { ft from south riser, } 70 \text { inches } \\
\text { from tank bottom }\end{array}$ \\
\hline
\end{tabular}

